$\begin{array}{cc}\text { Türk Coğrafya Dergisi } \\ \text { Basılı ISSN 1302-5856 } & \text { Turkish Geographical Review } \\ \text { www.tcd.org.tr } & \text { Elektronik ISSN 1308-9773 }\end{array}$

\title{
Karstlaşmanın insan yaşamı üzerindeki sınırlandırıcı etkisinin CBS tabanlı mekânsal istatistik analizleri ile saptanması (Arapgir-Malatya Platosu)
}

\author{
Determination of the limiting effect of karstification on human life with GIS-based \\ spatial statistical analyzes (Arapgir-Malatya Plateau) \\ Pınar Polat ${ }^{*}$ (D) Murat Gömüç ${ }^{b}$ \\ ${ }^{a}$ Erzincan Binali Yıldırım Üniversitesi, Fen - Edebiyat Fakültesi, Coğrafya Bölümü, Erzincan, Türkiye. \\ ${ }^{b}$ Erzincan Binali Yıldırım Üniversitesi, Sosyal Bilimler Enstitüsü, Coğrafya Ana Bilim Dalı, Erzincan, Türkiye.
}

ORCID: P.P. 0000-0001-5846-0454; M.G. 0000-0002-6013-4620

\section{BILGI / INFO}

Geliş/Received: 30.09.2021

Kabul/Accepted: 30.11.2021

\section{Anahtar Kelimeler:}

Arapgir Platosu

Karstlaşma

CBS tabanlı mekânsal istatistik

Yerleşme seçimi ve arazi kullanım

\section{Keywords:}

Arapgir Plateau

Karstification

GIS based spatial statistics

Settlement selection and land use

*Sorumlu yazar/Corresponding author: (P. Polat)

ptaskiran@erzincan.edu.tr

DOI: $10.17211 /$ tcd.1002777

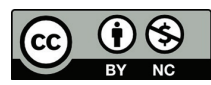

\section{Atff/Citation:}

Polat, P., \& Gömüç, M. (2021). Karstlaşmanın insan yaşamı üzerindeki sınırlandırıcı etkisinin CBS tabanlı mekânsal istatistik analizleri ile saptanması (Arapgir-Malatya Platosu). Türk Coğrafya Dergisi, (78), 75-90.

https://doi.org/10.17211/tcd.1002777

\section{ÖZ / ABSTRACT}

Munzur Kireçtaşları ve Alibonca Formasyonu'na ait marnlı-kumlu kireçtaşlarının yüzeylendiği Arapgir Platosu, çıplak ve sığ karstın geliştiği bir alandır. Fakat litostratigrafik farklılaşmaya bağlı olarak karstlaşmanın karakteri, litolojik birimler arasında farkılışmaktadır. Karstlaşma süreci, tektonik rejim farklılaşmaları ve iklim değişikliklerine bağlı olarak jeolojik geçmiş boyunca zaman zaman kesintilere maruz kalmış olsa da süreç devam etmiştir. Zaman içerisinde karstlaşmanın etkinliği yavaşlamış, flüvyal aşınım ve mekanik çözünme daha aktifleşmiş, lapya ve dolin oluşumları yer yer tahribata uğramıştır. Bu doğal tahribat ile sığ karst oluşumu bir araya gelince; su varlığı, toprak oluşumu ve vejetasyon açısından sınırlı, insan yaşamı ve beşeri faaliyetler açısından zorlu, taşık bir arazi ortaya çıkmıştr. Alanın bu mevcut durumundan dolayı, platonun bu kısmında hemen hemen hiçbir daimi yerleşme bulunmamakta ve tarımsal faaliyetler sınırlı olduğu için arazi kullanımı sadece yaylak-otlak alanı olarak gerçekleştirilmektedir. Bu çalışmanın amacı ve hedefi doğrultusunda, karstlaşmanın yerleşme seçimi ve arazi kullanımı üzerindeki sınılandırıcı ve belirleyici etkisini saptamak için karstik aşınım şekilleri uygulamalı ve basit rastgele örneklem metotlarına uygun bir şekilde sayısallaştırılarak, bir takım CBS tabanlı mekânsal istatistik analizlerine tabi tutulmuştur. Analizler sonucunda, karstlaşmanın yerleşme seçimi ve arazi kullanımı üzerinde sınırlandırıcı ve belirleyici bir etken olduğu istatistiksel olarak saptanmıştır.

The Arapgir Plateau, where the Munzur Limestones and the marly-sandy limestones of the Alibonca Formation are outcropped, is an area where bare and shallow karst structures develop, as in the general of the karst plateaus. However, the character of karstification differs among lithological units depending on lithostratigraphic differentiation. The karstification process has been interrupted throughout the geological past due to tectonic regime variations and climate changes and has tended to stagnate today. Thus, karstification was replaced by fluvial erosion and mechanical dissolution, and lapia and doline formations were damaged. The combination of this natural destruction and shallow karst formations has resulted in a stony terrain that is limited in terms of water availability, soil formation and vegetation, and challenging in terms of human life and human activities. Due to the current conditions of the area, there are almost no permanent settlements in this part of the plateau and since agricultural activities are limited, the land is used only as highland-grassland areas. In line with the aim and target of the present study, karst erosional patterns were digitized in accordance with applied and simple random sampling methods and subjected to a set of GIS-based spatial statistical analyses to determine the limiting and determining effect of karstification on settlement selection and land use. As a result of the analyzes carried out, it was statistically determined that karstification is a limiting and determining factor on settlement selection and land use. 
Extended Abstract Introduction

The Arapgir Plateau, chosen as the study area, is included in the Plateau Karst Area of the Eastern Anatolia Karst Region in terms of karstification character, since it is located in the Upper Euphrates Section of the Eastern Anatolia Region. The karstification process developed on the Munzur Limestones and the marly-sandy limestone members of the Alibonca Formation in the higher parts of the Arapgir Plateau (1500-1750 $\mathrm{m}$ ) within the boundaries of the study area. The karstification character of these two units, in which karstification has developed intensively, differs from one unit to another due to their different lithological and stratigraphic features (Iskender, 1994). While dolines developed on the Munzur Limestones, lapias, which are characteristic of shallow karst, developed on the marly-sandy limestone members of the Alibonca Formation (İskender, 1994). However, as in the whole of the Eastern Anatolia Region, the karstification process in the Arapgir Plateau has been interrupted due to tectonic regime changes and climatic variations. Therefore, the karst erosional shapes observed on the Arapgir Plateau today show paleokarstic features. So much so that most of the dolines were overcome by external drainage and destroyed by external factors (Iskender, 1994). This situation has made the difficult topographic conditions of the Arapgir Plateau even more challenging. Since this part of Arapgir Plateau reflects the characteristics of karst plateaus, it has limited opportunities for agricultural activities and is underpopulated. Due to this limiting effect of karst morphology, there are almost no permanent settlements in the higher parts of the Arapgir Plateau. In addition, karstification also affected the use of land and enabled this area to be used as a pasture-pasture area. The aim of this study is to introduce the features of the Arapgir Plateau in terms of karst morphology and to quantitatively reveal the limiting and determining effect of karstification on human life with GIS-based spatial statistical analyzes. The Arapgir Plateau, chosen as the study area, is located between $39^{\circ} 01^{\prime} 61.67^{\prime \prime}-39^{\circ} 08^{\prime} 22.23^{\prime \prime}$ northern latitudes and $38^{\circ} 36^{\prime} 50.24^{\prime \prime}-38^{\circ} 54^{\prime} 92.86^{\prime \prime}$ east longitudes within the borders of Arapgir district of Malatya province, which is located in the Upper Euphrates Section of the Eastern Anatolia Region. However, in this study, only the high parts of the Arapgir Plateau with an altitude of 1500 to $1750 \mathrm{~m}$ will be discussed. This area is roughly located to the west-northwest of Arapgir district center.

\section{Data and Method}

The study first started with a literature review. After the subject of the study was determined, the data obtained by scanning the sources related to the subject were brought together. A geomorphology, slope and location map of the study area was created by processing $1 / 25000$ scale topography maps obtained from HGM and high resolution $(x 12.5 \mathrm{~m})$ ASTERGDEM satellite images downloaded from Alospalsar in ArcMap 10.5 software for GIS analysis and creation of maps of the work area. The dolines were digitized, and their long sides calculated by Minimum Bounding Analysis. The geological map of the study area, on the other hand, was created as a result of combining the $1 / 100000$ scale geological maps from MTA, the existing data in the previous studies related to the study area and MTA Earth Sciences Editor. High resolution (x18m) satellite images of the study area were downloaded from the SAS Planet program and transferred to the ArcMap 10.5 program and the border of the micro study area (shallow karst area) was drawn. After the micro study area was determined, the study area was divided into equal $250 \mathrm{~m}^{2}$ boxes in accordance with the applied sampling method and a number was given to each box consecutively. As a result of this process, the area of the study was determined by creating 148 boxes. After determining the size of the area, Sekaran's sample table was taken as a basis and the sample size was determined as 103 boxes. In the analysis of the data, the simple random sampling method, which is one of the applied samples, was chosen so that each element in the field has an equal chance of being selected (Özgen \& Karadoğan, 2016). The numbers given to the boxes within the scope of the simple random sampling method were transferred to the IBM SPSS 22 program, respectively, and Random Sample Analysis was performed. The numbers were evenly distributed. 103 boxes, to which the numbers obtained as a result of the scattering process belong, were determined as samples and the karst erosion shapes in the boxes were digitized as point vector data. After the digitization of the karstic erosion patterns, the settlements within the study area were digitized as the point vector data by entering the 2020 ADKNS population data. Then, a land use map was created by using the CORINE (2018) data. The Nearest Neighborhood, Kernel Density, Mean Center and Standard Deviation Ellipse analyzes were performed and the relationship between karstification in the study area, settlement selection and land use was determined statistically after the data set required for the analysis was produced. The field work began when the office work was completed. Surveys were carried out for the study area and karstic erosion patterns were determined and photographed. With the completion of the field studies, all the data and findings obtained were brought together and the article writing phase started.

\section{Results and Discussion}

The Arapgir Plateau was exposed to continuous uplifting movements with the neotectonic period and moved away from the morphological base level and gained the high plateau appearance of today. Munzur Limestones and sandy-marly limestones belonging to Alibonca Formation crop out in the part of the plateau that is the source of the study. Although the character of karstification changes depending on the lithostratigraphic differentiation between these two lithological units, generally shallow karst formation is observed. It is possible to encounter doline formations in the study area, which is rich in lapya formations as a characteristic of shallow karst. However, tectonic regime variations and climatic changes led to a polycyclic cycle in the evolution of karst erosional patterns and to a stagnation tendency of karstification today. Therefore, karstification was replaced by fluvial erosion and mechanical dissolution, and karst erosional forms were largely destroyed by gaining paleokarst characteristics. Arapgir Plateau has limited opportunities in terms of water, soil and vegetation and has a stony and rugged topography. There are almost no permanent settlements in this part of the plateau, as this results in land unsuitable for agriculture and water deprivation. In addition, karstification also affected land use 
and enabled this area to be used as a pasture-pasture area. As a result of the analyzes carried out, karst erosion patterns and population density were determined, and the location of karst erosion patterns and settlement and settled population were determined statistically. According to the results of the analysis, it was determined that the karst erosional forms intensified in the west of the study area to coincide with the high plateau area, and the settlements and population presence were concentrated on the lithological units, which are rich in agricultural activities and water potential, and where shallow karst formation is not observed in the east of the study area. In addition, it was determined that sparsely vegetated areas generally coincided with the karstification area, and various agricultural areas in the west were concentrated in the east, coinciding with the areas where Pliocene aged basalts and shallow karst development were not observed. Thus, it was statistically proven that karstification is a limiting factor on the choice of settlement and land use. Such GIS-based spatial statistical analyzes should be used by geographers who focus on the interaction between nature and human, to provide a quantitative quality to geographical studies and increase the validity of the studies. In addition, these analyzes should be used by the management staff in the determination of karstic areas, the selection of settlements in these areas and the determination of land use status, and the findings obtained should be used as a basis for planning and investment studies.

\section{Giriş}

Jeotektonik özelliğinden dolayı Türkiye arazisinin \%40’ eriyebilen kayaçlardan meydana gelmektedir ve bu oran yeraltı karstı da dâhil edildiğinde \%60'ları bulmaktadır (Nazik \& Tuncer, 2010; Nazik \& Poyraz, 2015, 2017). Karst morfolojisi; topoğrafya koşullarını, zemindeki su, toprak ve bitki örtüsünü tayin etmesi açısından diğer morfolojik birimler gibi insan yaşamı üzerinde belirleyici bir etkiye sahiptir. Özellikle çıplak ve yüzeysel karstın geliştiği karstik platolar, zemindeki su ve toprak yoksunluğu nedeniyle tarımsal faaliyetler açısından sınırlı olanaklara sahiptirler ve bu özelliklerinden dolayı az nüfuslanmışlardır (Erinç, 2015; Ford \& Williams, 2007). Karstik alanların yaygın olduğu ülkemizde sığ karstın geliştiği alanlar insan yaşamı açısından güç mekânlardır. Yerleşme seçimi ve nüfus dağılışını etkileyen karstlaşma süreci, arazi kullanımını da etkilemektedir (Hadimli \& Bulut, 2008).

Eriyebilen kayaçların varlığına karşın, ülkemizdeki tektonik ve klimatik ortam koşullarının kısa mesafelerde değişmesi nedeniyle birbirinden farklı karakterlere sahip karst alanları ortaya çıkmıştır (Nazik \& Tuncer, 2010). Bu bakımdan çalışma alanı olarak seçilen Arapgir Platosu, Doğu Anadolu Bölgesi'nin Yukarı Fırat Bölümü’nde yer almasından dolayı karstlaşma karakteri olarak Doğu Anadolu Karst Bölgesi'nin, Plato Karst Alanı içerisine girmektedir (Nazik \& Tuncer, 2010; Nazik vd., 2019). Arapgir Platosu'nun, çalışma sınırı içerisinde kalan yüksek kısımlarında (1500-1750 metre) karstlaşma süreci daha çok Munzur Kireçtaşları ile Alibonca Formasyonu'nun marnlı-kumlu kireçtaşı üyeleri üzerinde gelişmiştir. Karstlaşmanın yoğun bir şekilde geliştiği bu iki birimin, farklı litolojik ve stratigrafik özelliklerinden dolayı karstlaşma karakteri birimden birime farklılaşmaktadır (Aktimur vd., 1995; İskender, 1994). Munzur Kireçtaşları üzerinde dolinler gelişirken, Alibonca Formasyo- nu'nun marnlı-kumlu kireçtaşı üyeleri üzerinde ise lapyalar gelişmiştir (İskender, 1994). Fakat Doğu Anadolu Bölgesi'nin tamamında olduğu gibi Arapgir Platosu'ndaki karstlaşma süreci de tektonik rejim değişikleri ve klimatik farklılaşmalara bağIı olarak kesintilere uğramıştır. Bundan dolayı bugün Arapgir Platosu üzerinde gözlemlenen karstik aşınım şekillerinin çoğu dış etkenler tarafindan tahrip edilmiştir (İskender, 1994). Bu durum, Arapgir Platosu'nun zorlu topoğrafik koşullarını daha da zorlaştırmıştır.

Karst morfolojisinin bu sınırlandırıcı etkisinden dolayı Arapgir Platosu'nun yüksek kısımlarında hemen hemen hiçbir daimi yerleşme bulunmamaktadır. Ayrıca karstlaşma arazi kullanımını da etkilemiş, bu alanın yaylak-otlak alanı olarak kullanılmasını sağlamıştır.

Bu çalışmanın amacı Arapgir Platosu'nun karst morfolojisi açısından özelliklerinin tanıtılarak, karstlaşmanın insan yaşamı üzerindeki sınırlandırıcı ve belirleyici etkisinin CBS tabanlı mekânsal istatistik analizleri ile kantitatif bir şekilde ortaya konulmasıdır. Bu bağlamda çalışma sonucunda, Arapgir Platosu üzerindeki karstlaşma süreci, yerleşme seçimi ve arazi kullanımı üzerinde etkin bir faktör müdür? Sorusunun cevaplanması hedeflenmektedir.

Çalışma alanı sığ karst oluşumu ve lapya çeşitliliği açısından oldukça zengindir. Güneysu (1993) tarafindan hazırlanan "Kovada Gölü Doğusunun (Isparta) Karst Jeomorfolojisi" adlı doktora tezi ile Kaymak (2018) tarafindan hazırlanan "Dim Çayı Havzası'nda (Alanya) Lapya Çeşitliliği" adlı makale çalışmasında bahsi geçen birçok sığ karst oluşumu çalışma alanında da görülmektedir. Yerleşme seçimi, arazi kullanımı ve coğrafi faktörler (jeoloji, jeomorfoloji, iklim vd.) arasındaki ilişkiye odaklanan çalışmalar (Özdemir vd., 2017; Çelik, 2019; Ford \& Williams, 2007; Koçyiğit \& Doğan, 2018; Doğan vd., 2017, 2019; Nazik vd., 2019; Öztürk, 2020; Öztürk vd., 2017) bulunmakla birlikte, doğrudan karstlaşma ile yerleşme seçimi ve arazi kullanımı arasındaki ilişkiye odaklanan çalışmalar da (Doğan, 1997; Güner, 2001; Hadimli \& Bulut, 2008; Siler \& Şengün, 2014) bulunmaktadır. Bu çalışma ise karstlaşmanın insan yaşamı üzerindeki sınırlandırıcı etkisini, CBS tabanlı mekânsal istatistik analizleri ile kantitatif bir şekilde ortaya koyması açısından bu alandaki diğer çalışmalardan ayrılmaktadır. Ayrıca bu tarz karst çalışmalarında daha önce kullanılmamış uygulamalı örneklem ve basit rastgele örneklem metotları da karstik aşınım şekillerinin sayısallaştırılması için bu çalışmada kullanılmıştır.

\section{1. Çalışma Alanın Yeri ve Konum Özellikleri}

Çalışma alanı olarak seçilen Arapgir Platosu, Doğu Anadolu Bölgesi'nin, Yukarı Fırat Bölümü'nde yer alan Malatya ilinin, Arapgir ilçesi sınırları içerisinde $39^{\circ} 01^{\prime} 61.67^{\prime \prime}$ - 39 $08^{\prime} 22.23^{\prime \prime}$ kuzey enlemleri ile $38^{\circ} 36^{\prime} 50.24^{\prime \prime}$ - 38 $54^{\circ}$ 92.86" doğu boylamları arasında yer almaktadır. Fakat bu çalışmada Arapgir Platosu'nun, yalnız 1500 ila 1750 m yükseltiye sahip yüksek kısımları ele alınacaktır. Bu alan ise kabaca Arapgir ilçe merkezinin batı-kuzeybatısındadır (Şekil 1). 


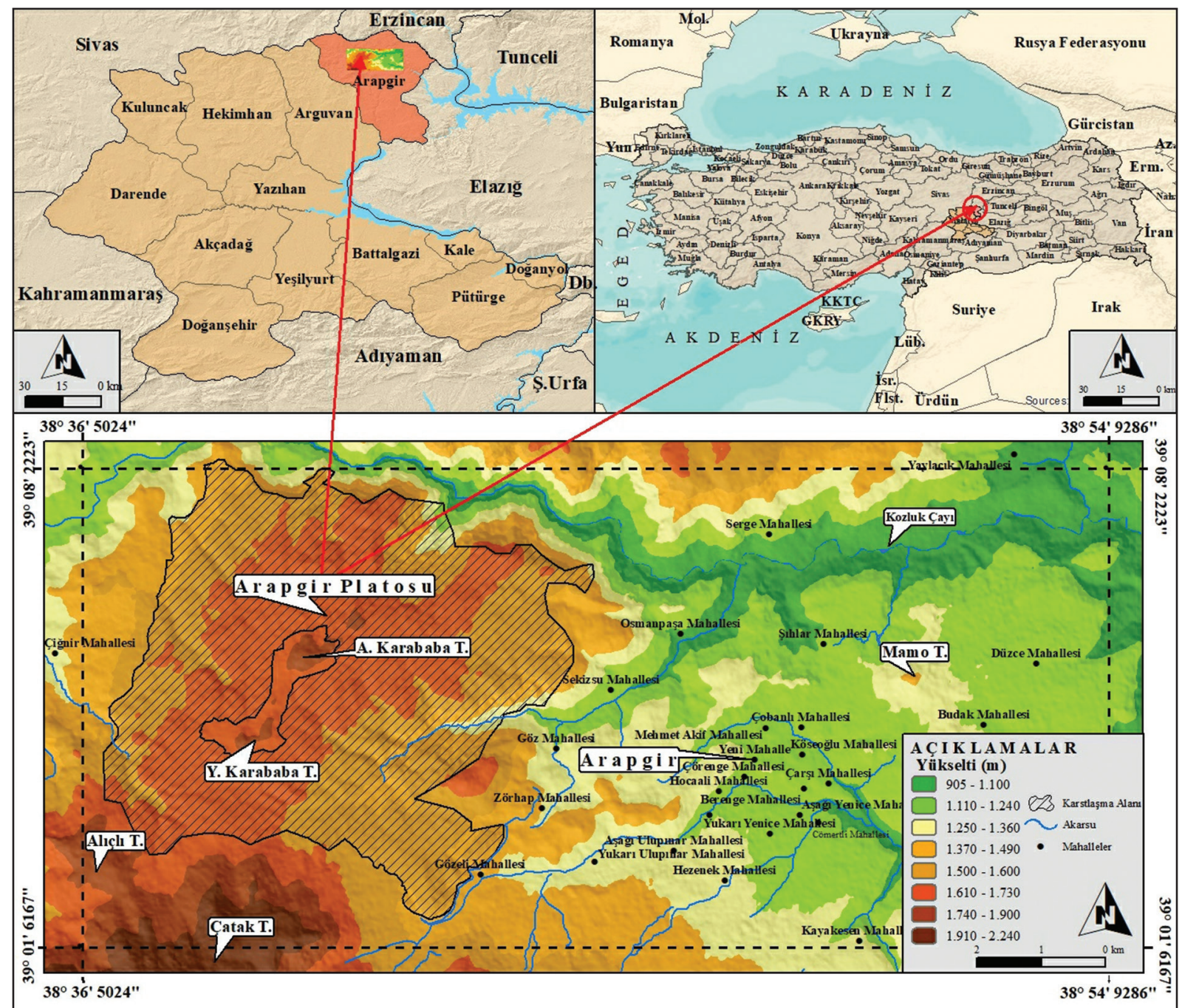

Şekil 1. Arapgir (Malatya) ve yakın çevresinin lokasyon haritası.

Figure 1. Location map of Arapgir (Malatya) and its immediate surroundings.

\section{Amaç ve Yöntem}

Çalışmaya ilk olarak literatür taraması ile başlanılmıştır. Çalışma konusu belirlendikten sonra konuyla ilgili kaynaklar taranarak elde edilen veriler bir araya getirilmiştir. Çalışma alanına ilişkin CBS (Coğrafi Bilgi Sistemleri) analizleri ve haritaların oluşturulması için Harita Genel Müdürlüğü'nden (HGM) temin edilen 1/25000 ölçekli topoğrafya haritaları ve Alos Palsar web adresinden indirilen yüksek çözünürlüklü ASTERGDEM verileri, ArcMap 10.5 yazılımında işlenerek çalışma alanına ait jeomorfoloji, eğim ve lokasyon haritası oluşturulmuştur. Dolinler, sayısallaştırılmış ve Minimum Bounding Geometry Analiziyle ${ }^{1}$ uzun kenarları hesaplanmıştır. Çalışma alanının jeoloji haritası ise Maden Tetkik ve Arama Genel Müdürlüğü'nden (MTA) alınan 1/100000 ölçekli jeoloji haritaları, çalışma alanıyla ilişkili önceki çalışmalar ve MTA Yer Bilimleri Editörü'nde yer alan mevcut verilerin bir araya getirilmesi sonucunda oluşturulmuştur. Çalışma alanına ilişkin yüksek çözünürlüklü (x18m) uydu görüntüleri SAS Planet programından indirilerek ArcMap 10.5 programına aktarıımış ve mikro çalışma alanının (sığ karst alanı) sınırı çizilmiştir. Mikro çalışma alanı belirlendikten sonra uygulamalı örneklem metoduna uygun olarak çalışma alanı birbirine eşit $250 \mathrm{~m}^{2 \prime}$ lik kutucuklara bölünmüş ve her bir kutucuğa ardışık olarak bir sayı verilmiştir. Bu işlem sonucunda
148 kutucuk oluşturularak çalışmanın evreni tespit edilmiştir. Evren büyüklüğünün saptanmasından sonra Sekaran'ın örneklem tablosu esas alınarak örneklem büyüklüğü 103 kutucuk olarak belirlenmiştir. Arazide yer alan her bir unsurun, eşit seçilme şansı olması için uygulamalı örneklemlerden basit rastgele örneklem metodu seçilmiştir (Özgen \& Karadoğan; Ölgen, 2016). Basit rastgele örneklem metodu kapsamında kutucuklara verilen bu sayılar, sırasıyla IBM SPSS 22 programına aktarılarak Random Sample Analizi yapılmış ve sayıların eşit bir şekilde dağılması sağlanmıştır. Dağılım işlemi sonucunda elde edilen sayıların ait olduğu 103 kutucuk, örneklem olarak belirlenmiş ve kutucuklar içerisindeki karstik aşınım şekilleri noktasal vektör veriler şeklinde sayısallaştırılmıştır (Şekil 2).

Karstik aşınım şekillerinin sayısallaştırılmasından sonra, çalışma alanı içerisine giren yerleşmeler; 2020 ADKNS nüfus verileri girilerek noktasal vektör veriler şeklinde sayısallaştırılmıştr. Daha sonra ise CORINE (2018) verilerinden yararlanılarak arazi kullanım haritası oluşturulmuştur. Analizler için gerekli olan veri seti üretildikten sonra En Yakın Komşuluk, Kernel Yoğunluk, Ortalama Merkez ve Standart Sapma Elipsi analizleri yapılarak çalışma alanındaki karstlaşma ile yerleşme seçimi ve arazi kullanımı arasındaki ilişki istatistiksel olarak saptanmıştır. Ofis çalışmalarının tamamlanmasıyla birlikte arazi çalışmaları-

\footnotetext{
1 https://asf.alaska.edu/data-sets/derived-data-sets/alos-palsar-rtc/alos-palsar-radiometric-terrain-correction/
}

2 https://pro.arcgis.com/en/pro-app/2.7/tool-reference/data-management/minimum-bounding-geometry.htm 

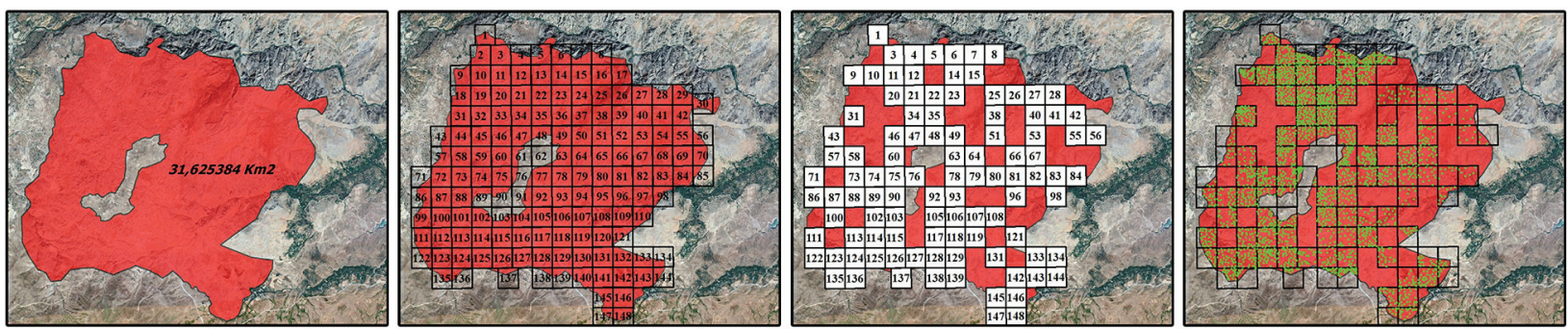

Şekil 2. Uydu görüntülerine göre belirlenen çalışma sınırı (1), uygulamalı örneklem metoduna göre çalışmanın evrenini temsil eden kutucuklar (2), basit rastgele örneklem metoduna göre çalışmanın örneklemini temsil eden kutucuklar (3) ve örneklem kutucuklarına göre sayısallaştırılmış karstik aşınım şekillerini ifade eden noktasal vektör veriler (4).

Figure 2. Operating limit (1) determined by satellite imagery, boxes representing the universe of the study according to applied sampling method (2), boxes representing the sample of the study according to simple random sampling method (3) and point vector data (4) which refers to digitized karstic apacity patterns according to sample tiles.

na geçilmiş, çalışma alanına yönelik etütler yapılmış ve karstik aşınım şekilleri tespit edilerek fotoğraflanmıştır. Arazi çalışmalarının da tamamlanmasıyla birlikte elde edilen tüm veriler ve bulgular bir araya getirilerek makale yazım aşamasına geçilmiştir.

\section{Karstlaşma Etkenleri}

Karstlaşma sürecinin meydana gelmesinde kayacın karakteri asıl etkendir. Fakat karst morfolojisinin gelişebilmesi için litolojik etkenler ile birlikte tektonik, yükselti, hidrolojik-klimatik, vejetatif ve zaman faktörü gibi etkenlerin de uygun olması gerekir (Pekcan, 2019).

\subsection{Jeolojik Etkenler}

Çalışma alanındaki birimlerden, Munzur Kireçtaşları ile Alibonca Formasyonu'na ait marnlı-kumlu kireçtaşları üzerinde karstik aşınım şekilleri gelişmiştir. Fakat birimler arasındaki litostratigrafik farklılaşmaya bağı ılarak karstlaşmanın karakteri ve karstik şekiller farklılaşmaktadır (Şekil 3).

\subsubsection{Munzur Kireçtașları (Orta-Üst Triyas-Kretase)}

Orta-Üst Triyas-Kretase yaşlı bu birim, Liyas-Kampaniyen araIığında çökelmiş platform tipi kayaçlardan meydana gelmekte ve Keban Metamorfitleriyle dokanaklı bir yapı göstermektedir (Özgül, 1981; Özer, 1994; İskender, 1994).

Munzur Kireçtaşları, altta oldukça saf neritik kireçtaşlarıyla başlar ve üst düzeylerde pelajik-çakmaktaşlı kireçtaşları ile son bulur (Özgül, 1981). Saf kireçtaşlarının varlığına bağlı olarak, porozite ve permabilite kabiliyeti oldukça iyi olan bu birimin üzerinde, tabaka kalınlığının yeterli olması ve karstlaşma sürecinin uzun sürmesinden dolayı karstik sahaların karakteristik oluşumlarından olan dolinler gelişmiştir (İskender, 1994; Fotoğraf 1).

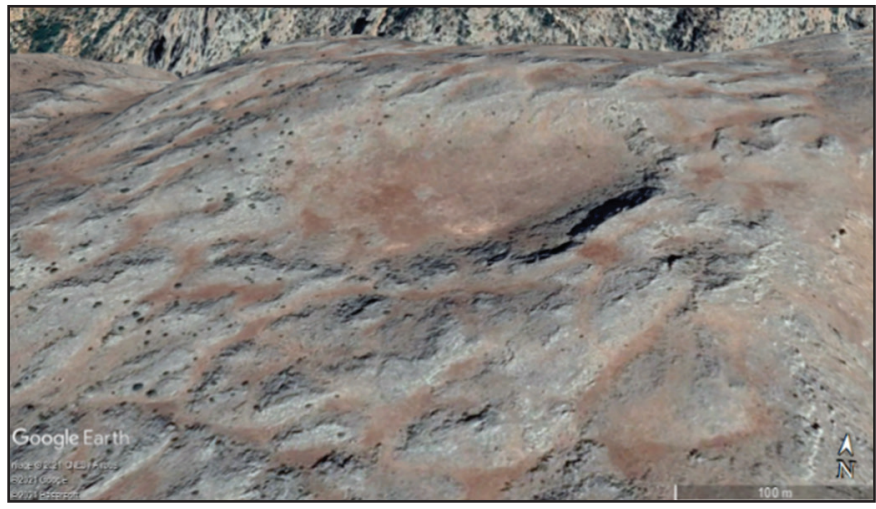

Fotoğraf 1. Munzur Kireçtaşları üzerinde gelişen dolinlerin 15.11.2021 tarihl Google Earth Görüntüsü.

Photograph 1. Google Earth Image of dolines developing on Munzur Limestones dated 15.11.2021.

\subsubsection{Alibonca Formasyonu (Alt Miyosen)}

Alt Miyosen yaşlı bu birim, taban kısmında kalın tabakalı ve yer yer masif yapılı kireçtaşları ile başlayarak, üst düzeylere doğru kumtaşı ara seviyeleri ihtiva eden marnlara geçer ve alttaki Keban Metamorfitleri'ni uyumsuzlukla örter (Baytaşoğlu, 2012).

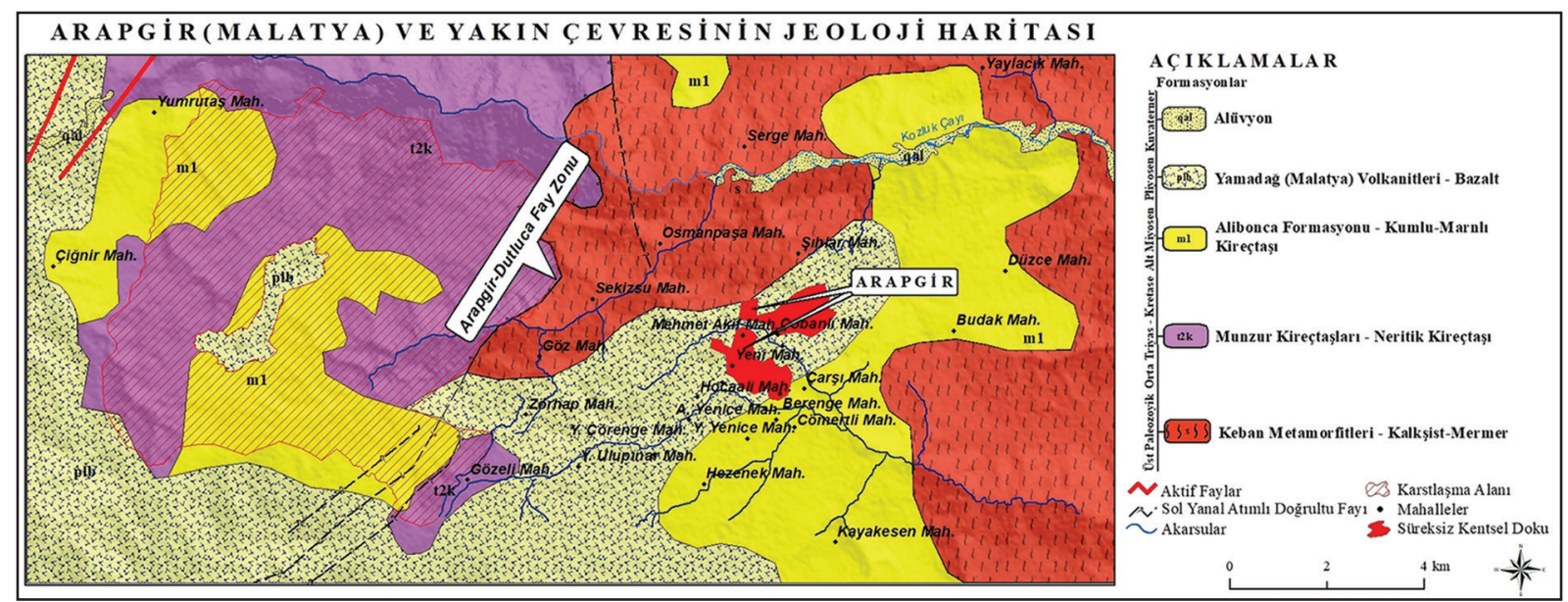

Şekil 3. Arapgir (Malatya) yakın çevresinin jeoloji haritası.

Figure 3. Geological map of Arapgir (Malatya). 
Alibonca Formasyonu'na ait kireçtaşları; kalsit, dolomit ve kilden oluşan bir matriksle birbirine bağlandığından inhomojen bir yapıdadır (Sönmez, 2004; Baytaşoğlu, 2012). Bu birimin ihtiva ettiği inhomojenliğe ve özellikle de killi unsurların varlığına bağlı olarak, kireçtaşlarının porozite ve permabilite kabiliyeti düşüktür. Porozite ve permabilite kabiliyetinin düşüklüğüne ilaveten, tabaka kalınlığının fazla olmaması ve tektonik deformasyonlar, bu birim üzerinde derinlik karstının gelişmesini engellemiştir. Ayrıca bu birim Munzur Kireçtaşları'na göre daha genç olduğundan, neotektonik dönemdeki devamlı yükselme rejimiyle birlikte karstlaşma süreci daha kısa sürmüş ve sığ karstın karakteristiği olan lapyalar gelişmiştir (İskender, 1994; Fotoğraf 2).

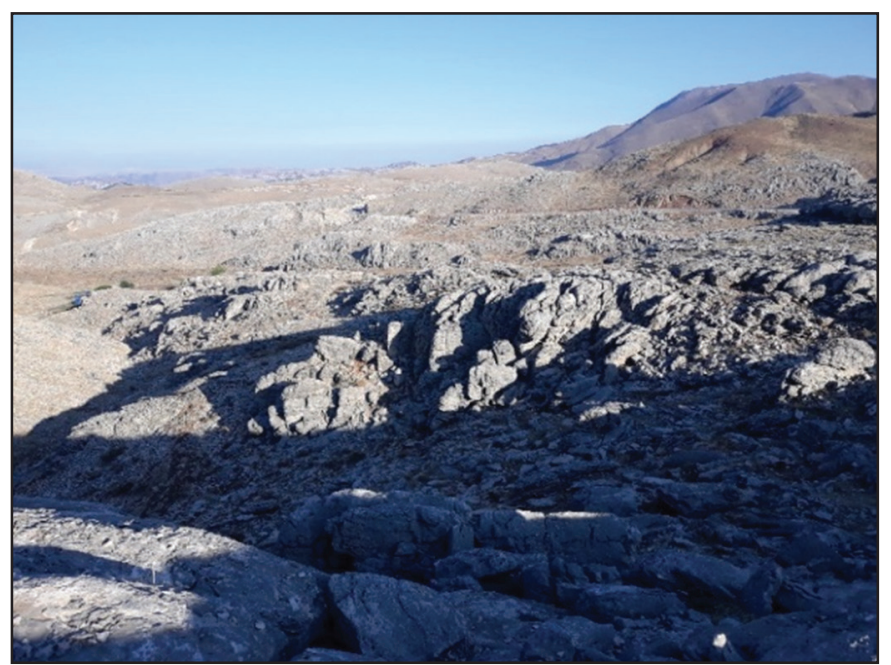

Fotoğraf 2. Alibonca Formasyonu üzerinde, sıyrılma yüzeylerinde gelişen lapyalar. Photograph 2. Lapyas developing on the Alibonca Formation.

\subsection{Jeomorfolojik Etkenler}

Arapgir çevresindeki jeomorfolojik oluşumlar; tektonizma, volkanizma, flüvyal aşınım, karstlaşma, kütle hareketleri ve erozyon gibi süreçler tarafindan belirlenmiştir. Bu süreçlerden karstlaşma ise en iyi yüksek plato alanlarında gelişim göstermiştir. Bu alanlardaki karst morfolojisi daha çok lapyalardan meydana gelen sığ karst tipinde olsa da dolin benzeri oluşumları görmek mümkündür (Şekil 4). Karstik kaide seviyesi, yükselti ve eğim, fay ve çatlaklar gibi karstlaşmayı etkileyen faktörler bu bağlamda ele alınmıştır.

\subsubsection{Karstik kaide seviyesi}

Arapgir Platosu, Doğu Anadolu Bölgesi'nin tamamında olduğu gibi neotektonik dönemin başlamasına yol açan kıta-kıta çarpışmasıyla birlikte kompresyonel hareketlere maruz kalmış ve devamlı olarak morfolojik kaide seviyesinden uzaklaşarak bugünkü yükseltisini kazanmıştır (Nazik \& Poyraz, 2015).

Bu paleokarstik şekillerden Alibonca Formasyonu üzerinde gelişenlerin jeolojik geçmişteki karstik kaide seviyesi; kil, kum veya marn depolarının seviyelerine göre belirlenirken, Munzur Kireçtaşları üzerinde ise alttaki Keban Metamorfitleri'nin şist, kalkşist ve mermer gibi üyeleri tarafindan belirlenmiştir. Munzur Kireçtaşları üzerinde karstik kaide seviyesi daha derinde olduğundan bu birim üzerinde kısmen derinlik karst gelişirken, Alibonca Formasyonu' nda ise karstik kaide seviyesi yüzeye daha yakın olduğundan sadece sığ karst gelişebilmiştir (İskender, 1994).

\subsubsection{Yükselti ve eğim}

Yüksek bölgelere çıkıldıkça karstik şekiller zenginleştiğinden, Arapgir Platosu'nun 1500 ila 1750 m’lere karşılık gelen yüksek kısımlarında, karstik şekiller oldukça yoğunlaşmaktadır. Arapgir Platosu'nda karstik şekiller aynı yükselti kuşağı içerisinde, iç içe geçmiş bir şekilde görülmektedir. Bu durum karstlaşma karakterindeki asıl farklılaşmanın, yükseltiden çok litolojik farklılaşmadan kaynaklandığını ve karstik şekillerin, polisiklik bir döngünün eseri olan şekiller olduğunu doğrulamaktadır.

Karstlaşma üzerindeki bir diğer önemli etken ise çözünme sürecini yönlendiren eğim derecesidir. Eğim derecesinin fazla olduğu alanlarda su, yüzey üzerinde uzun bir süre kalamadığından, eğim derecesinin çok düşük olduğu düz alanlarda ise durgun suyun korrozyon kabiliyeti düşük olduğundan çözünme süreci zayıflar. Bundan dolayı suyun beslenebildiği fakat çok hızlı akmadığı hafif eğimli alanlarda karstlaşma en iyi şekilde gelişir (Keser, 2004). Bu durumu Arapgir Platosu'nda da görmek mümkündür. Örneğin, eğim derecesinin $0-23^{\circ}$ olduğu hafif eğimli düzlük alanlarda karstik şekillerin yoğunlaşth̆̆, Göz Vadisi'nin veya dönemlik akarsuların yamaçlarında ise eğim derecesinin artmasına bağlı olarak, karstik şekil yoğunluğunun zayıfladığı görülmektedir.

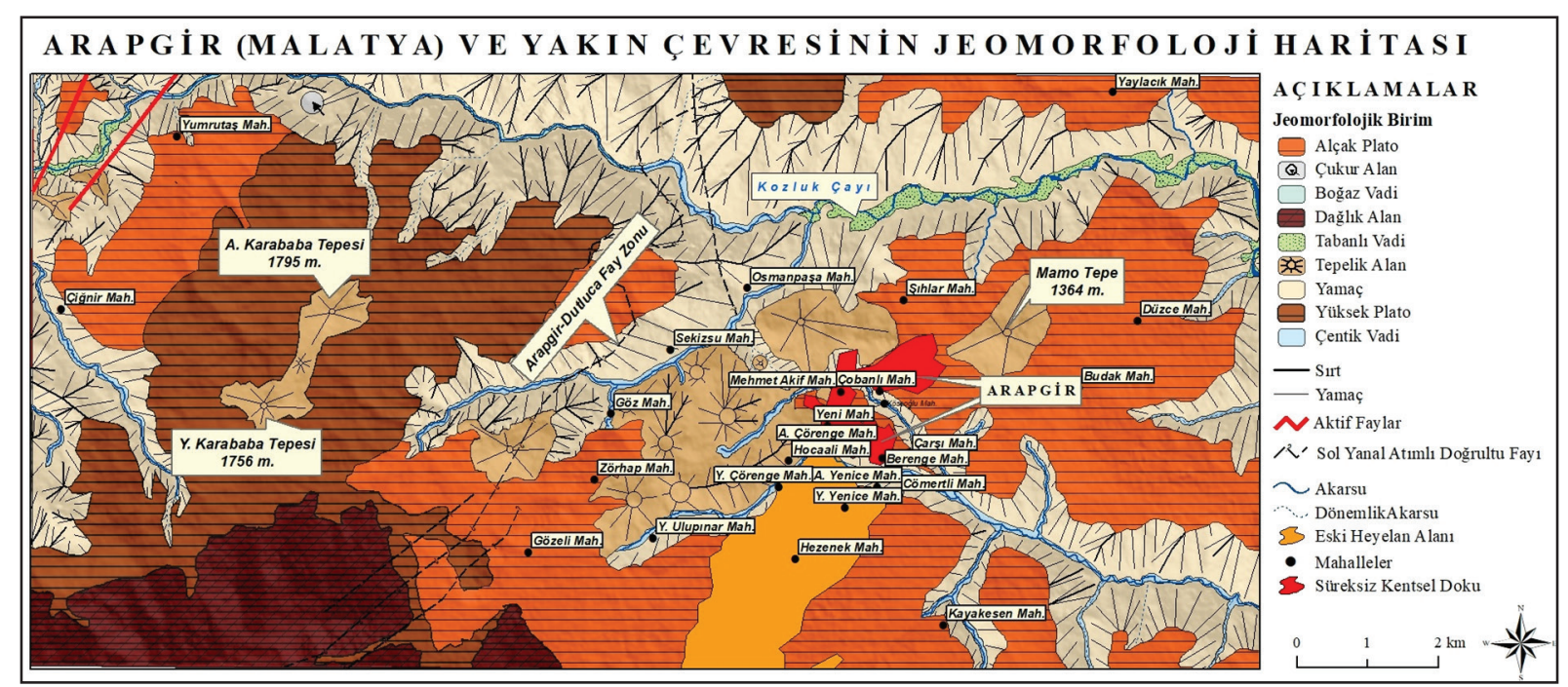

Şekil 4. Arapgir (Malatya) ve yakın çevresinin sadeleştirilmiş jeomorfoloji haritası.

Figure 4. Geomorphology map of Arapgir (Malatya) and its immediate surroundings. 

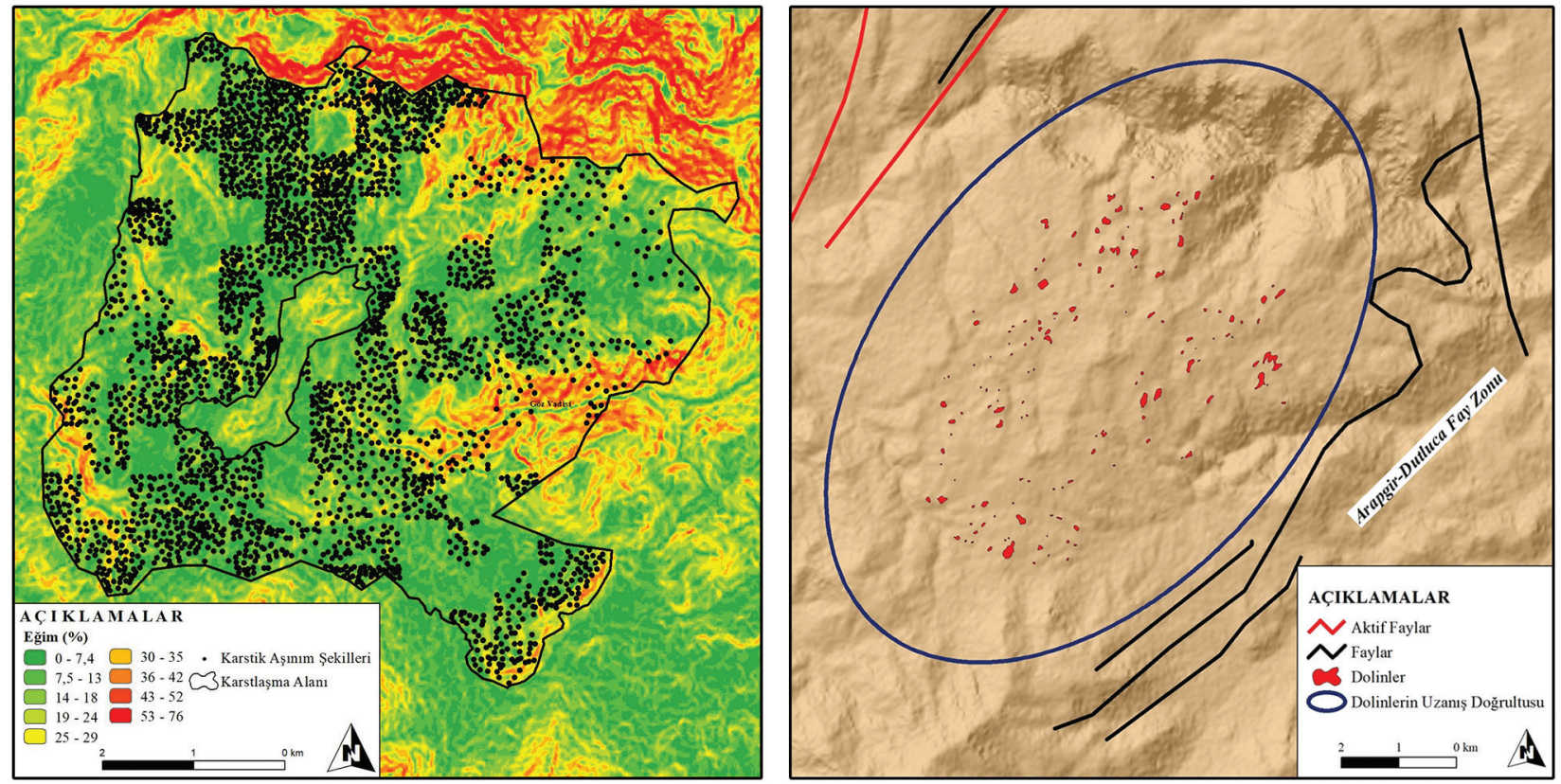

Şekil 5. Arapgir Platosu'ndaki karstik aşınım şekillerinin eğim derecelerine göre dağılımı (1) ve dolinler ile kırık sistemleri arasındaki ilişki (2).

Figure 5. Distribution of karstic apacity patterns on Arapgir Plateau by degree of inclination (1) and relationship between dolins and fracture systems (2).

\subsubsection{Fay ve Çatlaklar}

Çözünme süreci ile fay ve çatlaklar arasında doğrudan bir ilişki olduğundan, karstik şekiller genellikle fay ve çatlak sistemlerine paralel bir şekilde gelişirler. Çünkü tektonik deformasyonlarla oluşan kırık sistemleri, porozite ile permabilite kabiliyetini artırıp, çözünme sürecini hızlandırılarak karstik aşınım şekillerinin oluşmasını kolaylaştırırlar (Pekcan, 2019). Bundan dolayı bir alanda karstlaşmanın meydana gelebilmesi için kırık sistemlerinin varlığı olmazsa olmazdır.

Arapgir Platosu üzerinde ise özellikle dolinler, Arapgir-Dutluca Fayı'na paralel bir şekilde güneybatt-kuzeydoğu doğrultusunda uzanmaktadır. Bu durum karstlaşmanın tektonizma kontrolünde geliştiğinin en büyük kanıtıdır (Şekil 5).

\subsection{Klimatik-Hidrolojik Etkenler}

Çözünme sürecini meydana getiren suyun niteliği, büyük ölçüde klimatik koşullar tarafindan belirlenmektedir. Buharlaşma miktarının düşüklüğüne bağlı olarak soğuk sular, ılık sulara göre daha fazla $\mathrm{CO}^{2}$ ihtiva ettiğinden eritme kabiliyeti yüksektir. Fakat $\mathrm{CO}^{2}$ miktarının düşüklüğüne karşın, ılık suların da eritme hızı daha yüksektir (Pekcan, 2019). Bundan dolayı su karakterinin farklılaşmasına bağlı olarak, farklı klimatik bölgeleri karakterize eden karst tipleri meydana gelmiştir (Erinç, 2015).

Meteoroloji Genel Müdürlüğü (MGM) rasat verilerine göre Arapgir'in (1200 m) ortalama sıcaklığı $11,9^{\circ} \mathrm{C}$, ortalama yıllık yağış miktarı ise 746,9 mm'dir (Uysal, 2011). Arapgir Platosu üzerinde ise bu değerler yükseltinin etkisiyle farklılaşmaktadır. Ortalama sıcaklık 10,7 ile $9,3{ }^{\circ} \mathrm{C}^{\prime}$ ye düşmekte, yağış değerleri ise Schrieber formülüne göre 876 ile 1020 mm aralığına yükselmektedir. Aylık ortalama minimum ve maksimum sıcaklıklara bakıldığında ise en düşük minimum sıcaklığın $-6,0{ }^{\circ} \mathrm{C}$ ile ocak ayında, en yüksek maksimum sıcaklığın ise $29,7{ }^{\circ} \mathrm{C}$ ile ağustos ayında ölçüldüğü görülmektedir. Yıllık ortalama yağış miktarının mevsimsel değişimine bakıldığında ise Schrieber formülüne göre en fazla yağışın 386 mm ile kış mevsiminde, en az yağışın da 99,6 mm ile yaz mevsiminde (büyük çoğunluğunun haziran ayında) düştüğü görülmektedir (Şekil 6). Klimatik değerlere göre Arapgir Platosu civarında yaz ve kış mevsimi arasında sıcaklık ve yağış farkının fazlaca olduğu karasal iklim koşulları görülmektedir. Çalışma alanı, morfojenetik bölge sınıflamasına göre ise mekanik çözülmenin şiddetli olduğu yarı kurak bölgeler içerisine girmektedir (İskender, 1994).
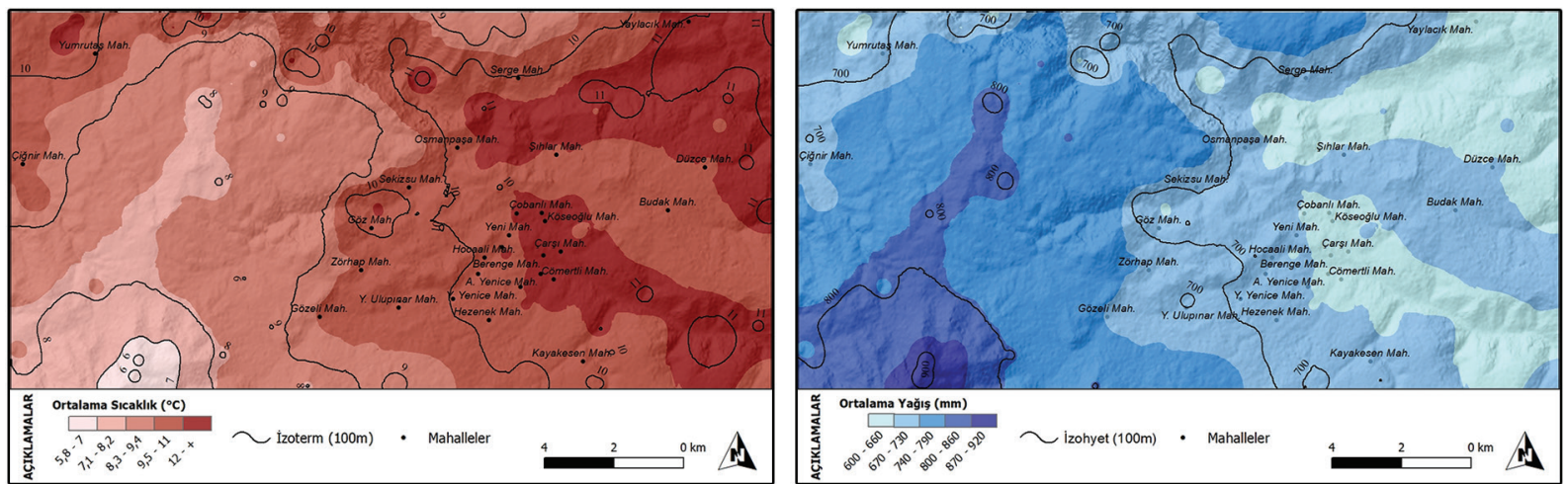

Şekil 6. Arapgir (Malatya) ve yakın çevresine ait uzun yıllar ortalama sıcaklık (1) ve yağış (2) haritası (1975-2009).

Figure 6. Map of average temperature (1) and precipitation (2) for many years in Arapgir (Malatya) and its immediate surroundings (1975-2009). 
Bu klimatik koşullara bağlı olarak, Arapgir Platosu'ndaki yağışın büyük bir kısmı kış aylarında kar yağışı olarak düşmekte ve donlu günlerin uzunluğuna bağlı olarak (84 gün) uzun bir süre yerde kalmaktadır. Yazları ise mevsimlik kuraklığa bağlı olarak yağış noksanı meydana gelmektedir (İskender, 1994). Bundan dolayı çalışma alanındaki suyun karakteri karstlaşma süreci için uygun, $\mathrm{CO}^{2}$ açısından zengin ve soğuk olmasına rağmen kış mevsiminde fizyolojik kuraklık, yaz mevsiminde ise mevsimlik kuraklık meydana geldiğinden yüzeyde karstlaşma süreci devam edememektedir. Ayrıca jeotektonik hareketler nedeniyle de karstlaşma süreci durduğundan, flüvyal aşınıma bağlı olarak plato üzerindeki suların büyük bir çoğunluğu geçici akarsularla dış drenaja açılmakta ya da kayacın porozite ve permabilite kabiliyetine bağlı olarak yer altına sızmaktadır. Bütün bu özellikler göz önüne alındığında günümüz koşullarına göre karstlaşma sürecinin meydana gelmesini sağlayan suyun, çalışma alanı içerisinde yeteri kadar etkinlik gösteremediği görülmektedir.

Sonuç olarak bu klimatik-hidrolojik değerlere göre, Arapgir Platosu'ndaki mevcut karstik şekillerin bugünkü klimatik koşullardan çok daha önce başlamış olduğu, geçmiş jeolojik dönemlerdeki kaide seviyelerine göre, daha sıcak ve nemli veya serin ve yağışlı klimatik koşullarda gelişmiş ve halen oluşumlarına devam eden şekiller olduğu görülmektedir.

\subsection{Vejetatif etkenler}

Vejetatif etkenlerin karstlaşma süreci üzerinde dolaylı bir etkisi bulunmaktadır. Bitki varlığı açısından zengin alanlarda, fotosentez olayının fazlalığına bağlı olarak havada ve toprakta $\mathrm{CO}^{2}$ miktarı arttğından, suyun korrozyon kabiliyeti artar. Fakat bu alanlarda toprak kalınlığının fazla olması suyun yeraltına sızmasını sınırlandırır. Vejetasyon açısından zayıf olan alanlarda ise fotosentez olayının düşüklüğüne bağlı olarak, havada ve toprakta $\mathrm{CO}^{2}$ miktarı düştüğünden suların ihtiva ettiği $\mathrm{CO} 2$ miktarı düşer (Pekcan, 2019). Bundan dolayı vejetasyonun çok gür olması veya çok zayıf olması karstlaşma üzerinde olumsuz etki yapar.

Arapgir Platosu'nun çalışmaya kaynaklık eden kısmında vejetasyon; Geven (Astra galus), Sığırkuyruğu (Verbascum), Deve dikeni (Alhagi camelerium), Yavşan otu (Artemisia), Sütleğen

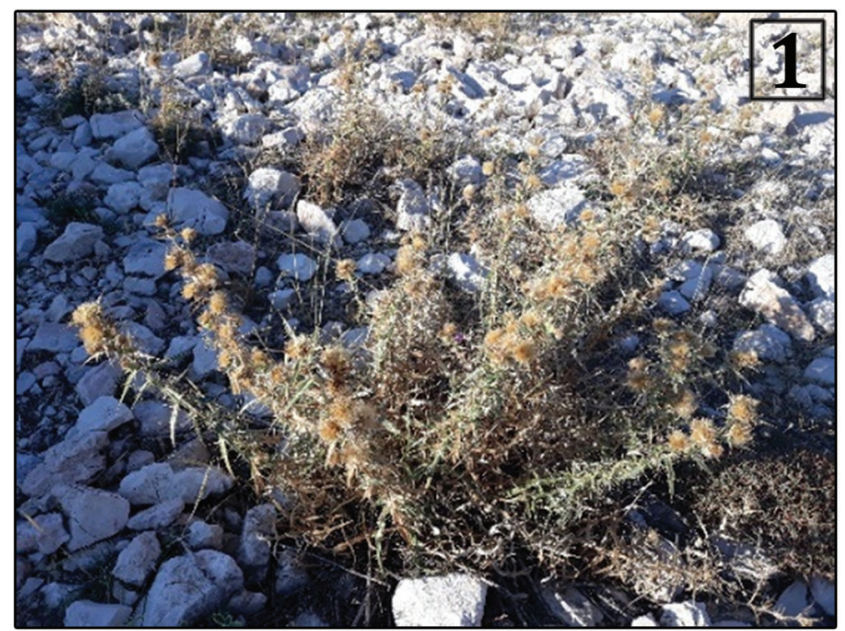

Fotoğraf 3. Kurakçıl otsu türlere ait görünümler (1-2).

Photograph 3. Views of the curtaceous herbaceous species (1-2).
(Euphorbia), Gelincik (Papaver), Kekik (Thymus) vb. gibi otsu türlerden meydana gelmekte (Fotoğraf 3), düzlük kısımlarda ise yüzeyi tamamen kaplayabilen çayır ve çimenler yetişmektedir (İskender, 1994). Fakat Arapgir Platosu'nun bu yüksek kısmında, vejetasyon gelişiminin sınırlandığı ve çıplak karst alanlarının ise yoğun bir şekilde geliştiği görülmektedir. Bu durum karstlaşma sürecine bağlı olarak, yüzeydeki suyun yeraltnna geçmesi veya geçici akarsular ile drene edilerek alandan uzaklaştırılması sonucunda oluşmuştur. Aynı zamanda bu durumun tersi bir tabirle, çalışma alanının ekolojik ortam koşullarından dolayı sadece otsu türlerin gelişebilmesi, çıplak karst oluşumunu kolaylaştırmış olabilir. Yani vejetasyon ile karstlaşma süreci arasında karşılıklı bir ilişki bulunmaktadır.

\subsection{Zaman Faktörü}

Karst morfolojisinin oluşumundaki bir diğer önemli etken ise zaman faktörüdür. Karstlaşma sürecinin meydana gelebilmesi için gerekli olan diğer etkenler de uygunsa, sürenin doğru uzunlukta olması karst morfolojisinin oluşumu için uygun bir ortam meydana getirir. Fakat geçmiş jeolojik dönemler içerisinde pek çok kez gelişen klimatik değişiklikler, deniz seviyesi oynamaları (östatik hareketler) ve tektonizmaya bağlı oluşan kabuk hareketleri gibi olaylar karstik şekillerin evriminde polisiklik bir döngünün yaşanmasına veya kesintilere yol açmaktadır (Pekcan, 2019).

Temel yapının Keban Metamorfitleri'nden meydana geldiği çaIışma alanı, Güneydoğu Anadolu Sürüklenim Kuşağı içerisinde yer aldığından, paleotektonik dönem boyunca kuzey-güney doğrultulu yanal yönde yer değiştirmelere maruz kalmıştır. Liyas-Kampaniyen aralı̆̆ında platform tipi Munzur Kireçtaşları'nın çökelmesi ile Keban Metamorfitleri arasında bir dokanak meydana gelmiş, neotektonik dönem öncesinde yaşanan transgresyon sonucunda ise Alt Miyosen yaşlı Alibonca Formasyonu'na ait kumlu-marnlı kireçtaşları çökelerek, Keban Metamorfitleri üzerindeki aşınım şekillerini örtmüştür. Fakat bu sedimantasyon sürecine karşın, genel ölçüde çalışma alanı Alt Miyosen'e kadar aşınıma maruz kalarak peneplen halini almıştır (İskender, 1994). Orta Miyosen'de Bitlis Sütur Kuşağı boyunca Avrasya ve Arap levhalarının çarpışmasıyla, paleotektonik dönem sona ermiş ve neotektonik dönem başlamıştır (Şaroğlu \& Güner, 1981). Neotektonik dönemle birlikte tek-

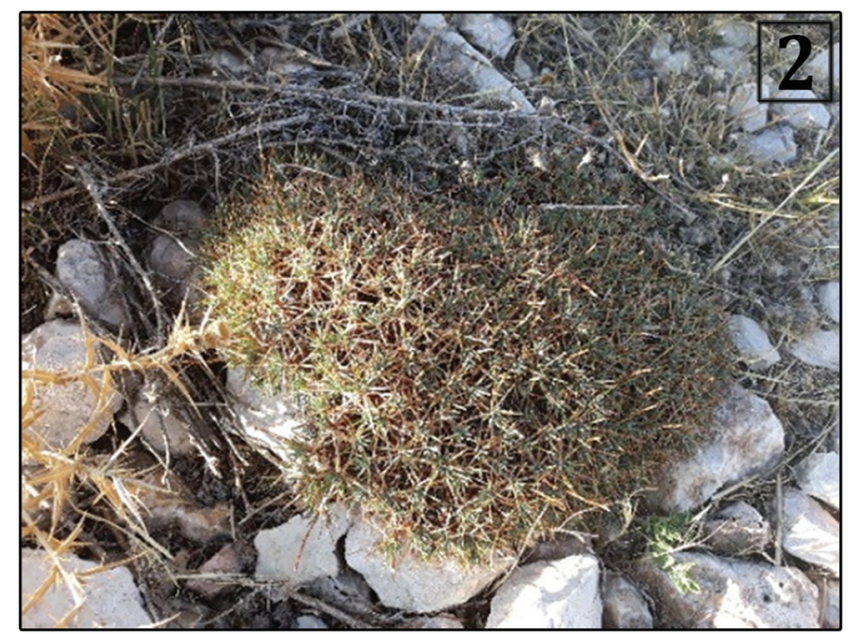


tonik rejim değişikliği yaşanarak, yanal hareketler yerini fasılalı dikey hareketlere bırakmıştır (Tonbul, 1987; İskender, 1994). Dikey yöndeki yükselim hareketlerine bağlı olarak Arapgir Platosu, morfolojik kaide seviyesinden uzaklaşarak bugünkü yükseltisini kazanmıştır. Bu yükselim hareketi süreklilik arz ettiğinden belirgin bir karstik kaide seviyesi oluşamamıştır. Oligosen dönemiyle birlikte ise Arap Levhası'nın kuzeye doğru hareketi, Doğu Anadolu üzerinde sıkışmaya yol açthğından Anadolu'nun kuzeyinde sağ-yanal doğrultu atımlı Kuzey Anadolu Fayı (KAF), güneyinde ise sol-yanal doğrultu atımlı Doğu Anadolu Fayı (DAF) gelişmiştir (Erinç, 1954). Anadolu Bloğu'nun doğu kısmı ise sol-yanal doğrultu atımlı Ovacık Fayı tarafindan ikiye ayrılmıştır. Ovacık Fayı'nın çalışma alanı içerisinde kalan kısmına Arapgir-Dutluca Fayı denilmekte ve bu fay güneydoğu-kuzeybatı doğrultusunda uzanmaktadır (Tatar, 1987; İskender, 1994). Pliyo-kuvaterner yaşlı olduğu tahmin edilen bu fay oluşumuna bağlı olarak, Arapgir Platosu'ndaki kireçtaşı veya mermer üyeleri üzerinde kırık sistemleri meydana gelmiş ve karstlaşmaya maruz kalarak karstik aşınım şekillerine dönüşmüştür.

Fakat tektonik faaliyetler kadar klimatik koşulların farklılaşması da karstlaşma üzerinde etkili olduğundan, karstlaşmanın karakteri zaman zaman değişmiştir. Üst Miyosen'de, Messiniyen krizi ile birlikte Akdeniz'in suları tamamen çekilmiş ve Anadolu çevresinde kuraklık etkili olmuştur. Pliyosen'de ise tektonik faaliyetler sonucunda Akdeniz Havzası'nda yeniden denizel ortam oluştuğundan suptropikal klimatik koşullar görülmüştür. Fakat Pliyosen döneminin ortalarından itibaren sıcaklıklar dünya genelinde düşme eğilimi içerisine girmiş, yüksek enlemlerde soğuk ve kurak, Akdeniz çanağı çevresinde ise serin ve yağışlı klimatik koşullar etkili olmuştur. Bu soğuma eğilimi Pleyistosen dönemiyle birlikte iyice ağırlık kazanarak pek çok kez farklılaşmıştır. Özellikle orta enlemlerin kuzeyinde yağış miktarlarında bir azalma meydana gelirken, suptropikal klimatik koşulların yaşandığı Akdeniz çevresinde ise bir yağış fazlası meydana gelmiştir. Pleyistosen döneminden Holosen'e geçişte günümüzden yaklaşık 9000 yıl önce kurak bir evre yaşanmış ve Anadolu'daki plüvyal göller kurumuştur. Günümüzden 6000 ila 8000 yıl önce ise Orta Holosen döneminde Klimatik Optimum olarak adlandırılan, ılık ve yağışlı bir evre hâkim olmuştur. Bu dönemden sonrada günümüz klimatik koşullarına benzer koşullar ortaya çıkmış ve ufak çaplı klimatik salınımlar meydana gelse de pek fazla değişmemiştir (Erol, 1992).

Munzur Kireçtaşları üzerinde gelişim gösteren dolinlerin, Pliyo-Kuvaterner yaşlı Arapgir-Dutluca Fayı'na paralel bir şekilde gelişmiş olması, bu birim üzerindeki karstlaşmanın; tektonizma kontrolünde, Pliyo-Kuvaterner dönemin serin yağışlı iklim koşullarında etkinlik kazandığını göstermektedir. Alt Miyosen yaşlı Alibonca Formasyonu inhomojen bir yapıda olduğundan, bu birim üzerindeki karstlaşma gelişimi sınırlanmıştır. Aynı zamanda Munzur Kireçtaşları daha yaşlı bir birim olduğundan, karstlaşma Pliyo-Kuvaterner dönemi öncesindeki sıcak ve nemli iklim koşullarında başlamış olabileceğinden, faylanmayla birlikte karstlaşma daha ileri bir seviyeye ulaşarak dolinler gelişmiş olabilir. Pleyistosen dönemi boyunca iklim karakteri pek çok kez değiştiğinden karstlaşma süreci kesintiler yaşamıştrr. Günümüz koşullarının hâkim olmaya başladığı Orta Holosen sonrasında ise muhtemelen kontinentalite değeri yüksek ve mekanik çözülmenin şiddetli olduğu klimatik koşullar ortaya çıkmış, karstlaşma neredeyse durma eğilimine girmiştir.
Böylelikle mevcut karstik şekiller, polisiklik bir döngü sonucunda meydana gelen şekiller halini almıştır.

Sonuç olarak, Arapgir Platosu üzerindeki karstlaşma süreci klimatik değişiklikler ve tektonik rejim farklılaşmalarına bağIı olarak zaman zaman kesintiye uğramış ve günümüzde ise karstlaşma yavaşlamıştır.

\section{Karstik Aşınım Şekilleri}

\subsection{Lapyalar}

Karst morfolojisinin en küçük aşınım şekillerini meydana getiren mikro-karstik şekillere lapya denilir (Erinç, 2015). Lapyalar, morfolojik gelişim açısından gençlik evresinin karakteristik şekilleri olmakla birlikte araziyi üzerinde yürünemeyecek kadar engebeli bir hale getiren küçük girinti ve çıkıntılardır. Lapyalar, hemen hemen tüm iklim koşulları altında oluşabilse de nemli ve sıcak iklimlerde daha büyük ve yuvarlak köşeli şekiller olarak görülürken, soğuk iklim koşularının hâkim olduğu yüksek alanlarda eriyen kar suları ve buzul etkisine bağlı olarak daha keskin hatlara sahip nivo-karstik şekiller olarak görülürler (Pekcan, 2019).

Bögli'nin (1960) lapya sınıflandırmasına göre; Arapgir Platosu üzerinde lapya türlerinden, daha çok serbest lapyalar görülmekle birlikte yarı serbest ve örtülü lapyalar da bulunmaktadır. Yüzeysel suların etkin olduğu eğimli yamaçlar üzerinde daha çok serbest lapyalardan kanalcıklı ve oluklu lapyalar görülürken, eğimin azaldığı düz alanlarda ise oyuklu, delikli lapyalar veya drop (yağmur damlası) izleri görülmektedir. Örtülü lapyalardan kovuklu lapyalar ise daha çok terra-rosa benzeri kırmızımsı-kahverengi toprak örtüsü tarafindan doldurulmuş küçük delikler şeklinde bulunmaktadır. Ayrıca lapya oluşumunun sınırlandırıldığı çıplak kaya yüzeyleri üzerinde ripple (dalga izleri) benzeri kimyasal çözünme dalgacıkları yer almaktadır.

\subsubsection{Kanalcıklı lapyalar}

Arapgir Platosu üzerindeki dönemlik akarsu vadilerinin veya nispi yükseltisi fazla tepelik alanların yamaçlarında, eğim derecesinin artmasına bağı ılarak serbest lapyalardan kanalcıklı lapyalar görülmektedir. Kanalcıklı lapyaların derinliği yer yer 40-50 cm'yi, uzunluğu ise 4-5 m'yi bulabilmektedir. Çalışma alanındaki karstlaşma sürecinin yavaşlamasına bağlı olarak, dönemlik sel suları tarafindan bu kanallar aşındırılarak yer yer aşınım artığı enkazlarla doldurulmuş ve bazı kısımlarda kurakçıl otsu bitkiler gelişmiştir.

\subsubsection{Oluklu lapyalar}

Kanalcıklı lapyalar gibi oluklu lapyalar da eğim değerlerinin arttı̆ı kısımlarda gelişen fakat daha sığ karstik aşınım şekilleridir. Oluklu lapyalar, yağmur sularının doğrudan şekillendirici ve korrozif etkisiyle oluşan oldukça güncel şekillerdir. Bu bakımdan oluklu lapyalar, karstlaşma sürecinin gençlik evresini karakterize ederler (Güneysu, 1993). Arapgir Platosu'nda, Alibonca Formasyonu'nun yüzeylendiği kısımlarda karstlaşma gençlik evresindeyken kesintiler başladığından bu şekillere oldukça sık rastlanılmaktadır (Fotoğraf 4). 

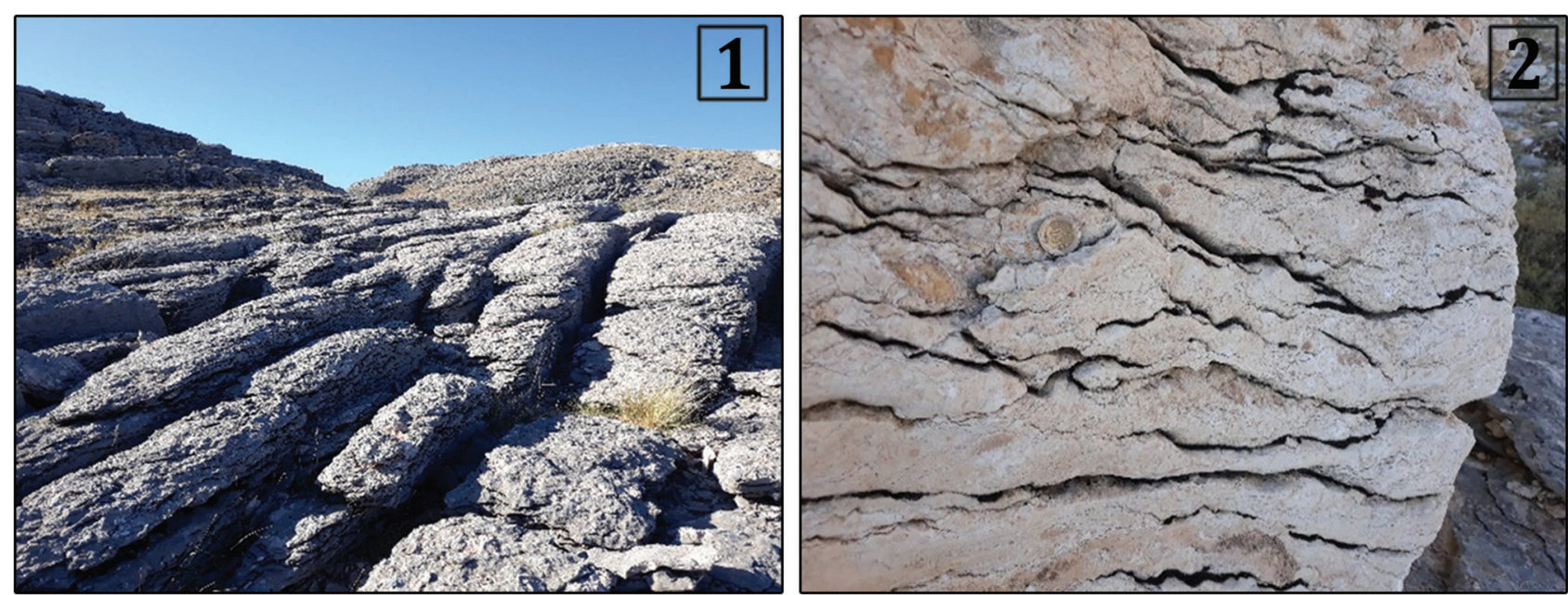

Fotoğraf 4. Kanalcıklı (1) ve oluklu (2) lapya örnekleri.

Photograph 4. Examples of lapya with ducts (1) and corrugated (2).

\subsubsection{Tabaka düzlemi ve diyaklaz lapyalar}

Kalsiyum karbonatlı birimlerden meydana gelen tabaka sistemlerinin tabakalaşma düzlemleri, karstlaşmanın gelişmesiyle birlikte suyun korrozif etkisine maruz kalarak tabaka düzlemi lapyalarına dönüşür (Koçak, 2003; Kaymak \& Kafalı Yılmaz, 2018). Çalışma alanı içerisinde bu tür lapya oluşumları, tabaka yapılarının geliştiği eğimli yamaçlar boyunca gözlemlenmektedir. Çalışma alanı zaman zaman tektonizmaya maruz kaldığından, litolojik birimler üzerinde diyaklazlar oluşmuştur. Bu yapıların karstlaşmaya maruz kalması sonucunda ise diyaklaz lapyalar meydana gelmiştir (Fotoğraf 5).

\subsubsection{Kimyasal çözünme dalgacıkları (ripple) ve damla (drop) izleri}

Daha önce de bahsi geçtiği üzere çalışma alanındaki karstlaşma süreci gençlik evresinde yavaşlamaya başladığından, Alibonca Formasyonu'nun bazı kısımlarında neredeyse lapya oluşumuna dahi izin vermeyecek kadar sığ bir karstlaşma görülmektedir. Bu alanlarda sadece ripple benzeri kimyasal çözünme dalgaları ile yağmur damlalarının korrozif etkisiyle oluşmuş drop izleri görülmektedir (Fotoğraf 6).
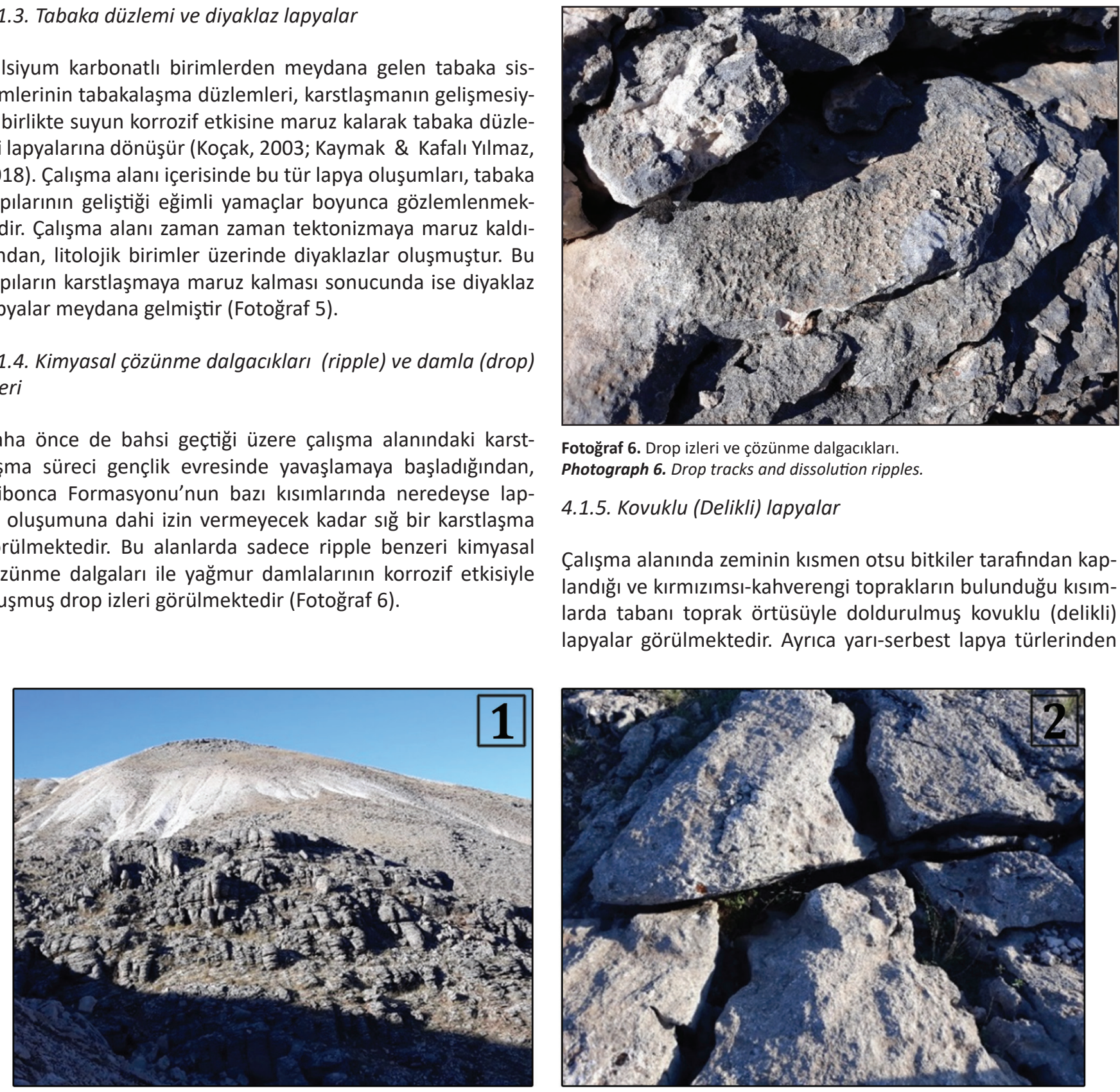

Fotoğraf 6. Drop izleri ve çözünme dalgacıkları.

Photograph 6. Drop tracks and dissolution ripples.

\subsubsection{Kovuklu (Delikli) lapyalar}

Çalışma alanında zeminin kısmen otsu bitkiler tarafindan kaplandığı ve kırmızımsı-kahverengi toprakların bulunduğu kısımlarda tabanı toprak örtüsüyle doldurulmuş kovuklu (delikli) lapyalar görülmektedir. Ayrıca yarı-serbest lapya türlerinden

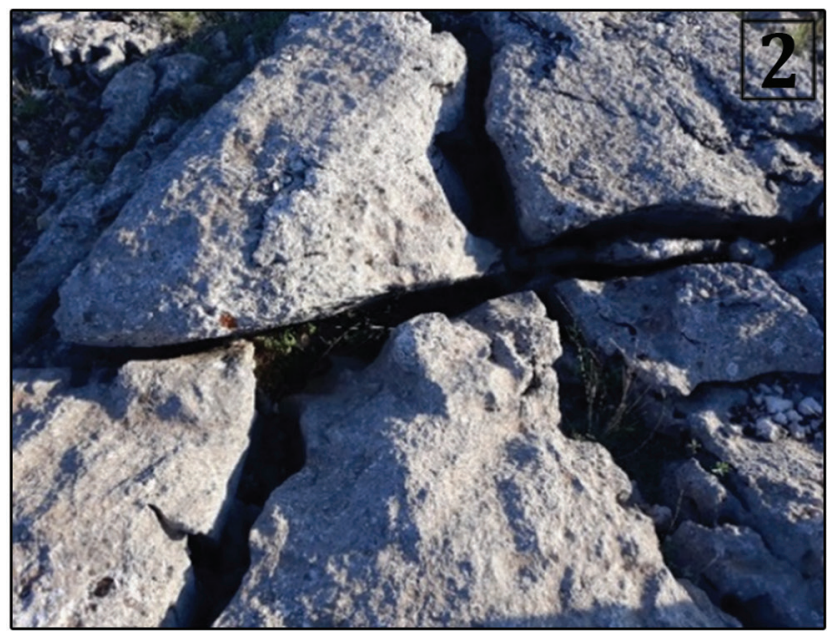

Fotoğraf 5. Tabaka düzlemi lapyalar (1) ve diyaklaz lapyalar (2). Photograph 5. Layer plane lapyas (1) and diaclase lapyas (2). 
kamenitsa ve korrozyon çentikleri gibi oluşumlara da rastlamak mümkündür.

\subsubsection{Lapya kompleksleri ve enkazları}

Daha önce bahsi geçen lapya türleri bir araya gelerek karmaşık bir yapı meydana getirirse, bu yapılara lapya kompleksleri denilir (Erinç, 2015). Arapgir Platosu üzerinde ise kanalcıklı, oluklu, oyuklu, kovuklu (delikli) vb. lapyaların bir araya gelmesiyle daha çok sivri lapya komplekslerine benzer bir yapı meydana gelmiştir (Fotoğraf 7).

Mekanik çözünmenin etkinlik kazanmasıyla birlikte lapyalardan ayrılan kayaç parçaları, kanalcıklar veyahut da çevresine göre daha çukur alanlarda depolanarak lapya enkazlarını meydana getirmektedir. Lapya enkazları ve çevreden taşınan diğer klastik unsurlar, araziyi adeta bir taş çölüne çevirerek üzerinde dahi yürünemeyecek bir hâl almasını sağlamıştir.

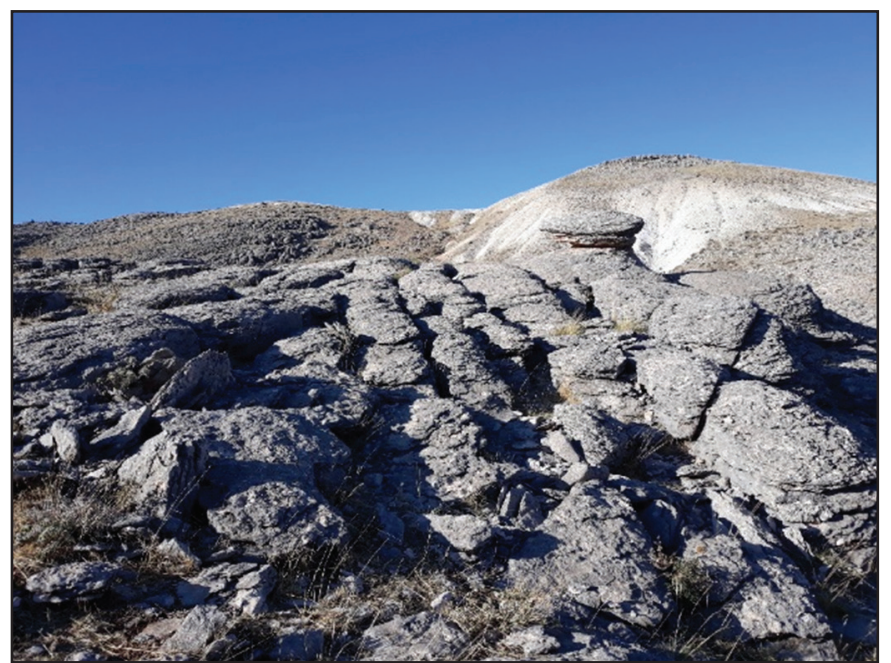

Fotoğraf 7. Sivri lapya kompleksleri.

Photograph 7. Pointed lapya complexes.

\subsection{Dolinler}

Karst morfolojisinin karakteristik şekillerinden olan dolinler, derinlikleri ve çapları birkaç metreyi bulan makro-karstik aşınım şekilleridir. Dolinlerin çapları genellikle derinliklerinden fazladır ve bu şekiller kazan, huni veya kuyu şeklinde görülebilmektedirler. Dolinlerin bu kadar çeşitli tiplerde görülmesinin nedeni, oluşum etkenine bağlı olarak çözünme ve çökme dolini olarak ikiye ayrılmasından kaynaklanmaktadır (Erinç, 2015). Arapgir Platosu'ndaki dolinler ise Arapgir-Dutluca Fayı'na bağlı olarak kuzeydoğu-güneybat doğrultusunda meydana gelen kırık ve çatlak sistemlerinde karstlaşmanın gelişmesiyle oluşan çözünme dolinleri şeklindedir (Fotoğraf 8).

Çözünme dolinleri, karstlaşmanın gençlik evresinin biraz ilerlemiş devresinde dikine veya verevine oluşan çatlakların meydana getirdiği, ruiniform (harabe) şekillerinin birleşmesi sonucunda oluşurlar (Pekcan, 2019). Çözünme dolinleri daha önce de bahsi geçtiği üzere, çalışma alanı içerisinde büyük ölçüde Munzur Kireçtaşları üzerinde görülmektedir.

Oluşumunda tektonizmanın oldukça etkin olduğu bu şekiller, karstlaşma sürecinin yavaşlamasına bağlı olarak büyük ölçüde tahrip olmuş, dönemlik akarsular tarafindan dış drenaja açılmış ve tabanları kaynağını Karababa Tepesi'nden alan volkanitlerle doldurulmuştur (İskender,1994). Taban kısmının kırmızımsı-kahverengi terra-rosa benzeri bir toprak örtüsüyle doldurulduğu kısımlarda ise kurakçıl otsu türler yayılışa geçmiştir. Bu durum, karstlaşmanın etkinliğinin yavaşlayarak yerini ağırlıklı olarak mekanik çözünme ve flüvyal aşınıma bıraktığını göstermektedir (Fotoğraf 9).

\section{Bulgular}

5.1. Karstlaşmanın İnsan Yaşamı Üzerindeki Etkisi

Jeomorfoloji, beşeri faaliyetlerin gerçekleştirilmesi açısından koşulları zorlaştıran ya da kolaylaştıran bir etken olması nedeniyle yerleşmelerin kurulup gelişmesi üzerinde oldukça

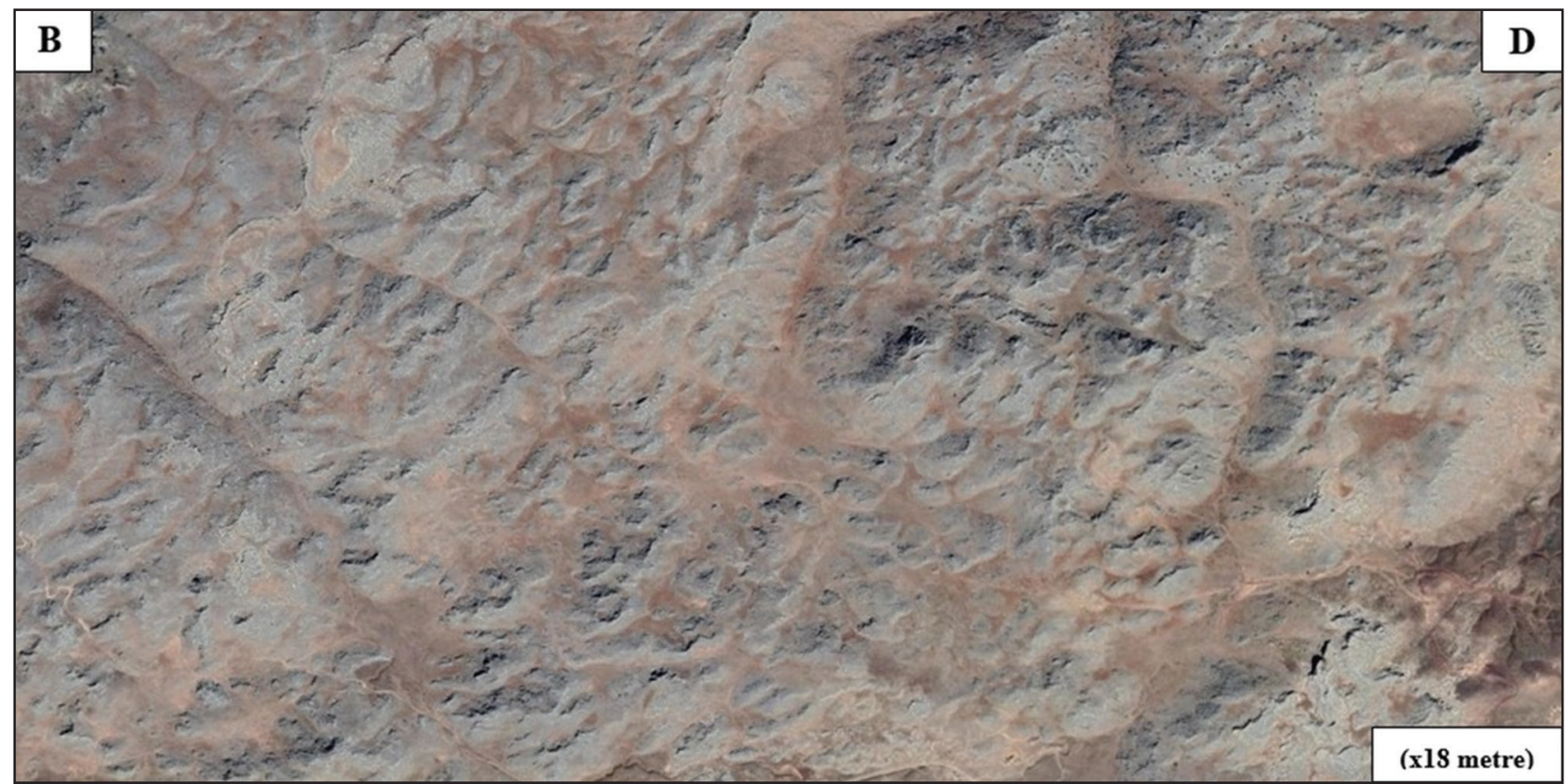

Fotoğraf 8. Arapgir Platosu'ndaki dolin oluşumlarına ilişkin 18 metre çözünürlüklü uydu görüntüsü. Photograph 8. Satellite image of dolin formations on Arapgir Plateau with a resolution of 18 meters. 


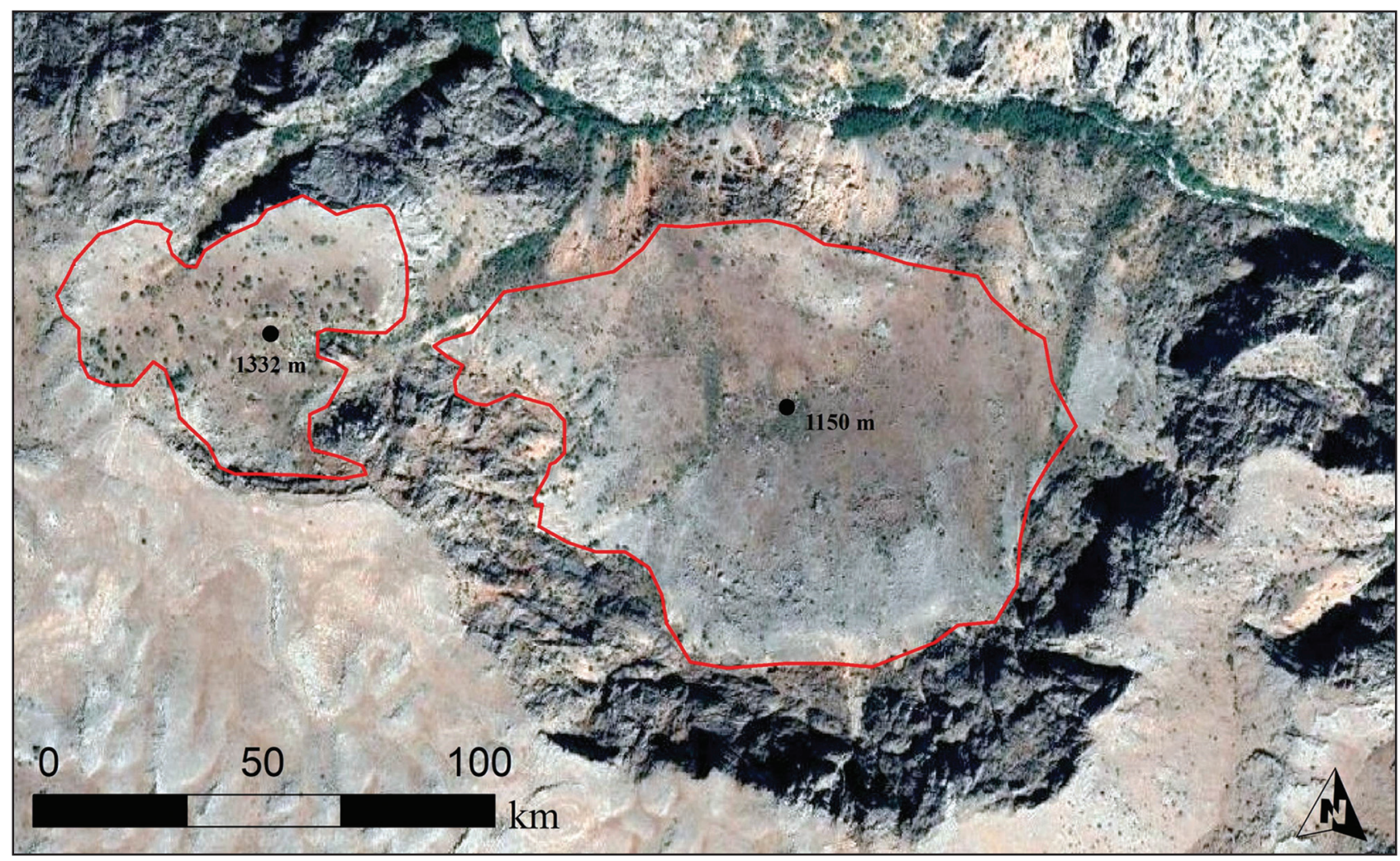

Fotoğraf 9. İnceleme alanında Büyükgöl Çukuru olarak bilinen Dolin oluşumları. Photograph 9. Doline formations known as Büyükgöl Pit in the study area.

etkilidir (Çelik, 2019). Jeomorfolojik oluşumu belirleyen süreçlerden karstlaşma, nüfus varlığı ve yerleşme seçimi üzerinde belirgin bir etkiye sahiptir. Polye ve uvala gibi makro karstik aşınım şekilleri, insan faaliyetlerine olanak tanıyan alanlar olduğu için daimi yerleşmelere ev sahipliği yaparken, lapya benzeri mikro karstik aşınım şekillerinin geliştiği sığ ve çıplak karst alanları ise zorlu topoğrafik koşullar nedeniyle az bir nüfusa ve geçici yerleşmelere ev sahipliği yapmaktadır (Hadimli \& Bulut, 2008). Örneğin Taşeli Platosu, çıplak karst gelişimine bağlı olarak beşeri faaliyetlerin sınırlandırıldığı engebeli bir morfolojiye sahip olması açısından, ülkemizin en seyrek nüfuslu alanlarından biridir (Siler \& Şengün, 2014). Muğla ili çevresinde plato yüzeyine kurulan köyler ise sınırlı tarım ve hayvancılık faaliyetlerine bağlı olarak, yörenin nüfusu en az ve geri kalmış yerleşmelerini oluşturmaktadırlar (Güner, 2001).

Arapgir Platosu'nun, çalışmaya kaynaklık eden yüksek kısımlarında su, toprak ve bitki yoksunluğu görülmektedir. Sığ karstın geliştiği bu alanlar, tarımsal faaliyetler açısından olumsuz olanaklara ve insan yaşamı açısından güç, taşlık ve arızalı bir topoğrafyaya sahip olduğundan hemen hemen hiçbir daimi yerleşme bulunmamaktadır. Bu alan yaylacılık faaliyetlerine bağlı olarak mevsimlik kullanıma sahne olmakta ve daha çok geçici yayla yerleşmeleri kurulmaktadır.

Karstlaşmanın Arapgir'deki yerleşme ve nüfus varlığının konumu üzerindeki sınırlandırıcı ve belirleyici etkisini ortaya koymak için ilk olarak En Yakın Komşuluk Analizi uygulanmıştır. Bu analizin çalışma mantığı, belirli bir alan içerisindeki noktasal vektör verilerin, birbirlerine olan mesafelerini ölçerek bu noktasal verilerin dağılım özelliklerinin saptanmasıdır. Analiz çıktılarından gözlenen mesafe değerinin, beklenen mesafe değerinden küçük olması halinde noktasal veriler arasındaki mesafenin olması gerekenden daha az olduğu, yani küme- lenmenin meydana geldiği görülür. En yakın komşuluk oranı 1 değerinden ne kadar uzaksa kümelenme o ölçüde fazladır. P-Değeri 0 ila 0,05 aralığında ise kümelenme istatistiksel olarak anlamlıdır. Sonuç olarak dağılım tipi de veri dağılımını göstermektedir.

Analiz sonuçlarına göre makro çalışma alanı içerisinde karstik aşınım şekillerinin 145,4 metre aralığında dağılması beklenirken, 56,4 metre aralığında dağıldığı, en yakın komşuluk oranın 1 değerinden uzak bir değer olarak 0,388084 olduğu, P-Değerinin ise 0,05 değerinden küçük bir değer olarak 0,00 olduğu ve sonuçta karstik aşınım şekillerinin, makro çalışma alanı içerisinde istatistiksel olarak anlamlı bir şekilde kümelendiği saptanmıştır. Yerleşmelerin ise 1505,3 metre aralığında dağılması beklenirken, 1188, 7841 metre aralığında dağıldığı, en yakın komşuluk oranının ise karstik aşınım şekillerine göre, 1 değerine daha yakın bir değer olarak 0,789714 olduğu, P-Değerinin 0,05 değerinden küçük bir değer olarak 0,03 olduğu ve sonuçta yerleşmelerin, karstik aşınım şekilleri kadar olmasa da makro çalışma alanı içerisinde anlamlı bir şekilde kümelendiği ortaya çıkmıştır (Tablo 1).

Tablo 1. Çalışma sınırına göre en yakın komşuluk analizi. Table 1. Nearest neighborhood analysis by working limit.

\begin{tabular}{|c|c|c|}
\hline \multicolumn{3}{|c|}{ En Yakın Komşuluk Analizi } \\
\hline & $\begin{array}{c}\text { Karstik Aşınım } \\
\text { Şekilleri }\end{array}$ & Yerleşmeler \\
\hline Gözlenen Mesafe & 56,4374 Metre & 1188,7841 Metre \\
\hline Beklenen Mesafe & 145,4256 Metre & 1505,3355 Metre \\
\hline $\begin{array}{c}\text { En Yakın Komşuluk } \\
\text { Oranı }\end{array}$ & 0,388084 & 0,789714 \\
\hline P-Değeri & 0,000000 & 0,036584 \\
\hline Dağılım Tipi & Kümeli & Kümeli \\
\hline
\end{tabular}




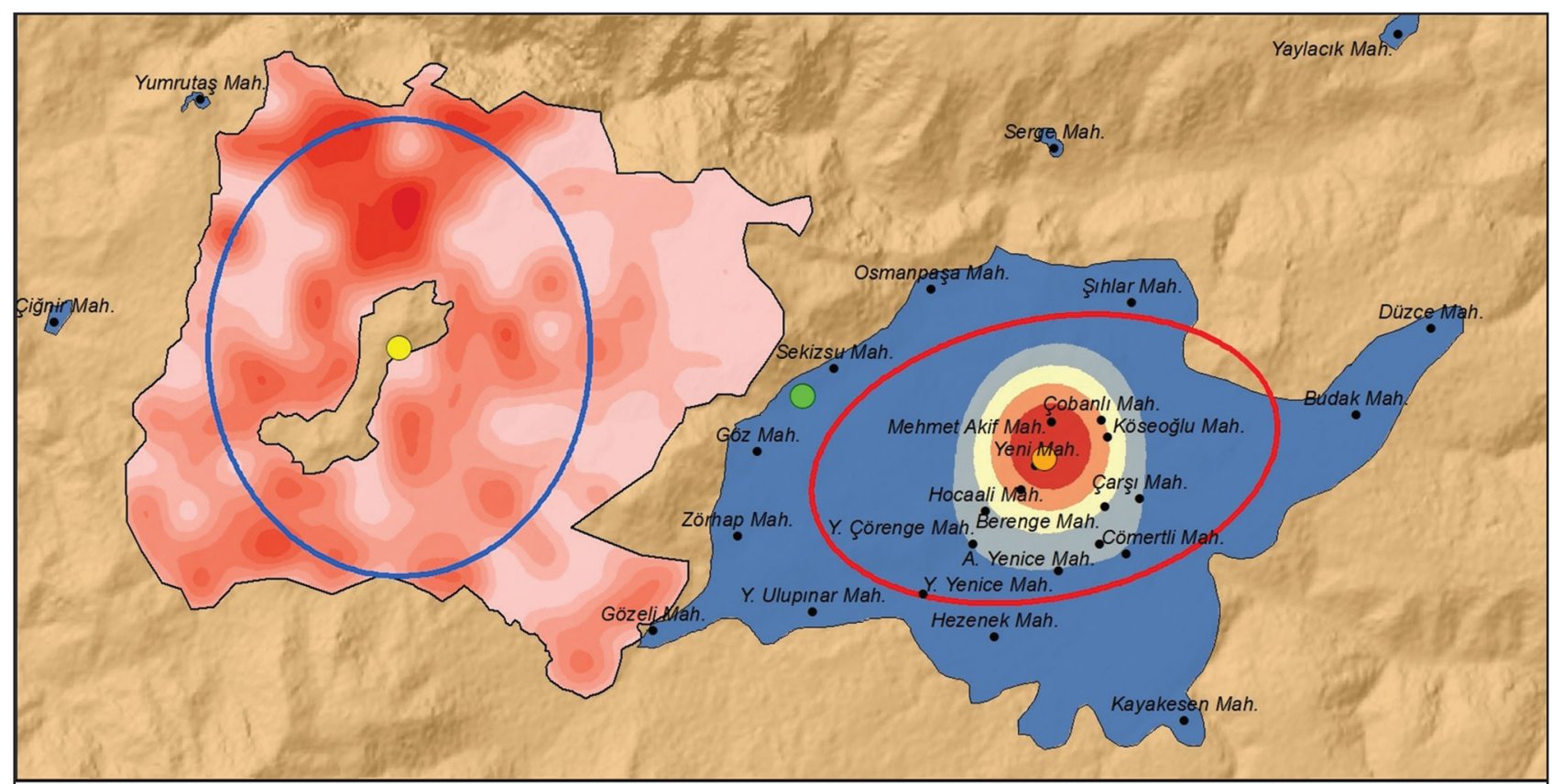

\section{AÇIKLAMALAR}

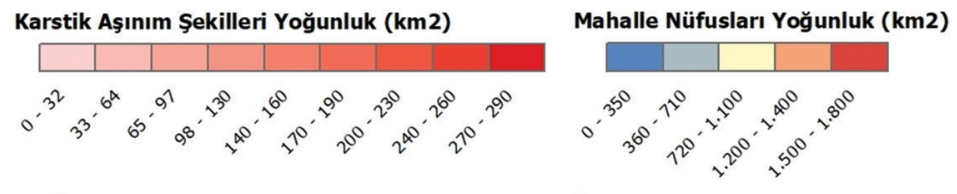

Karstik Aşınım Şekilleri Standart Sapma Elipsi

Mahalle Nüfusları Standart Sapma Elipsi

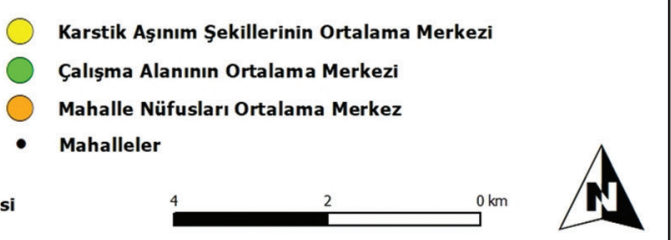

Şekil 7. Karstik aşınım şekilleri ve mahalle nüfuslarına göre Kernel Yoğunluk Analizi ile Ortalama ve Standart Sapma Elipsi Analizleri.

Figure 7. Kernel Density Analysis and Average and Standard Deviation Ellipse Analyses by Karstic apacity patterns and neighborhood populations.

Karstlaşmanın sınırlandırıcı etkisinin tam olarak saptanabilmesi için karstik aşınım şekillerinin ve yerleşmelerin hangi konumda kümelendiğinin de saptanması gerekmektedir. Bu durumu saptamak için Ortalama Merkez, Standart Sapma Elipsi ve Kernel Yoğunluk Analizi gibi analizler uygulanmıştır (Şekil 7).

Kernel Yoğunluk Analizi'ne göre karstik aşınım şekillerinin kuzey-kuzeybati ve güney-güneybatıda yoğunlaştı̆ı, doğu-kuzeydoğu ve güneydoğuda ise yoğunluğun (metamorfizma nedeniyle) düştüğü saptanmıştrr. Yerleşmeler ve nüfus varlığının ise karstlaşma alanını çevreleyecek şekilde çalışma alanının doğu-güneydoğusunda, özellikle de Arapgir ilçe merkezinde yoğunlaşt̆̆̆ saptanmıştır.

Ortalama Merkez Analizi ise girilen değerlere göre çalışma sınırı içerisindeki merkezi noktayı saptamaktadır. Yeşil renkli nokta, çalışma sınırına göre belirlenmiştir ve çalışmanın tam orta noktasını göstermektedir. Sarı nokta ise karstik aşınım şekilleri verisine göre, turuncu nokta ise yerleşme nüfusu verisine göre belirlenmiştir. Analiz sonucuna göre karstik aşınım şekillerini temsil eden sarı noktanın yeşil noktanın batısında bulunması karstik aşınım şekillerinin batıda konumlandığını gösterirken, yerleşme nüfusunu temsil eden turuncu noktanın ise yeşil noktanın doğusunda bulunuyor olması, yerleşme nüfusunun doğuda konumlandığını göstermektedir.

Standart Sapma Elipsi Analizi sonuçlarına göre karstik aşınım şekillerinin, kuzey-güney doğrultusunda yoğunlaştı̆ı, yerleşmeler ve nüfus varlığının ise güneybatı-kuzeydoğu doğrultusunda yoğunlaştığı saptanmıştır.
Tüm bu mekânsal istatistik analizleri sonucunda çalışma alanının batısında, sığ karst gelişimine bağlı olarak hiçbir daimi yerleşmenin bulunmadığı, yerleşmelerin ve nüfus varlığının ise karstlaşma alanını çevreleyecek şekilde çalışma alanın doğusunda, özellikle de Pliyosen yaşı bazaltlar üzerine kurulan Arapgir ilçe merkezinde yoğunlaştğı, en yoğun nüfuslu yerleşmenin ise Mehmet Akif Mahallesi olduğu istatistiksel olarak saptanmıştır. Yerleşmelerin güneybat-kuzeydoğu doğrultusunda uzanıyor olması ise kırık sistemleri ve bunun akabinde gelişen drenaj sisteminin bir sonucudur. Volkanik tepelerin de kırık sistemlerine paralel bir şekilde uzandığı arazi etütleri ve uydu görüntüleri vasıtasıyla tespit edilmiştir.

\subsection{Karstlaşmanın Arazi Kullanımı Üzerindeki Etkisi}

Arazi kullanımı, insan ve doğa arasındaki ilişkinin en önemli göstergesidir. Çünkü genel anlamda beşeri faaliyetler, doğal ortam koşulları ve morfoloji tarafindan belirlenmektedir. Arazinin sahip olduğu jeomorfolojik özellikler, arazi kullanımını kolaylaştırıcı ve yahut da zorlaştırıcı bir etkiye sahiptir. Bundan dolayı geçmişten beri insanoğlu arazi değerlendirmesi yaparken jeomorfolojik özellikleri de hesaba katmıştır (Özdemir vd., 2017).

Jeomorfolojik yapı olarak karst morfolojisi de arazi kullanımı üzerinde önemli bir etkendir. Karst morfolojisinin geliştiği alanlarda arazi kullanımı polye, uvala ve sınırlı da olsa dolin gibi makro karstik aşınım şekillerinde yoğunlaşırken, sığ ve çıplak karstın geliştiği plato alanlarında ise zorlu topoğrafik koşullar nedeniyle sınırlanmaktadır (Doğan, 1997; Erinç, 2015). Ül- 
kemizdeki kalker karst alanlarının büyük bir çoğunluğu orman ve yaylak-otlak alanı olarak kullanılmaktadır (Hadimli \& Bulut, 2008). Bu durumu Arapgir Platosu'nda da görmek mümkündür. Arapgir Platosu'nun batısındaki sığ karstın geliştiği alanlar, karstlaşma ve ekolojik ortam koşullarına bağlı olarak seyrek bitki örtüsünün geliştiği, su ve toprak yoksunluğu nedeniyle tarımsal faaliyetler açısından fakir bir alandır. Bundan dolayı bu alan, yaylacılık faaliyetine bağlı olarak yöre halkı tarafindan yaylak-otlak alanı olarak kullanılmaktadır.

CORINE 2018 verilerine göre tarım arazilerinin büyük bir kısmı, karstlaşma alanın güney-güneydoğu ve doğusunda yoğunlaşmaktadır. Aynı zamanda çeşitli orman ve süreksiz kentsel doku alanlarının da doğuda yoğunlaştı̆ı görülmektedir. Seyrek bitki örtülü alanlar ile doğal otlak alanlarının ise çalışma alanının batı-kuzeybat, kuzey ve güney-güneybatısında, genel anlamda sığ karst alanına denk gelecek şekilde yoğunlaşth̆̆ görülmektedir (Şekil 8).

CORINE 2018 verilerine göre, Ortalama Merkez ve Standart Sapma Elipsi analizleri uygulanmıştır. Analiz sonuçlarına göre; tarım alanlarını temsil eden mavi noktanın, çalışmanın tam orta noktasını gösteren yeşil noktanın doğu-güneydoğusunda bulunması; tarım alanlarının doğu-güneydoğuda konumlandığını, seyrek bitki örtüsünü temsil eden turuncu noktanın ise batıda bulunması, seyrek bitki örtülü alanların batıda konumlandığını göstermektedir. Fakat seyrek bitki örtülü alanların doğuda da fazlaca yer kaplamasından dolayı, seyrek bitki örtüsünü temsil eden nokta, çalışmanın ortalama merkezine yakın bir konumda bulunmuştur.

Standart Sapma Elipsi Analizi'ne göre tarım alanlarının güneybat-kuzeydoğu doğrultusunda, seyrek bitki örtülü alanların ise bat-kuzeybat ile doğu-güneydoğu doğrultusunda uzandığı saptanmıştir.

Arapgir Platosu'ndaki arazi kullanımının bu şekilde ortaya çıkmasında karstlaşma oldukça etkin bir faktördür. Çünkü sığ karst gelişimine bağlı olarak zeminde su ve toprak yoksunluğu meydana gelmiş, bu durum seyrek bitki örtüsü ve tarımsal faaliyetler açısından elverişsiz arazilerin ortaya çıkmasına neden olmuştur. Aynı zamanda süreksiz kentleşme alanı ve çeşitli tarım arazilerinin ise geniş ölçüde Pliyosen yaşlı bazaltlar veya Alibonca Formasyonu'na ait kireçtaşlarının sığ karst gelişimine elverişli olmayan alçak plato alanlarında yer aldığı görülmektedir. Çünkü bu alanlar ulaşım olanakları açısından elverişli, su kaynaklarına yakın ve toprak varlığı açısından zengin alanlara karşılık gelmekte, çalışma alanın batısına kıyasla yoğun bir arazi kullanımına sahne olmaktadır.

\section{Sonuç}

Arapgir Platosu'nun çalışmaya kaynaklık eden kısmında Munzur Kireçtaşları ve Alibonca Formasyonu'na ait kumlu-marnlı kireçtaşları yüzeylenmektedir. Bu iki litolojik birim arasındaki litostratigrafik farklılaşmaya bağı olarak karstlaşmanın karakteri değişse de genel ölçüde sığ karst oluşumu görülmektedir. Sığ karstın karakteristiği olarak lapya oluşumları açısından zengin olan çalışma alanında, dolin oluşumlarına da rastlamak mümkündür. Fakat tektonik rejim farklılaşmaları ve klimatik değişiklikler karstik aşınım şekillerinin evriminde polisiklik bir döngünün yaşanmasına ve günümüzde ise karstlaşmanın yavaşlama eğilimine girmesine yol açmıştır. Bundan dolayı karstlaşmanın yerini flüvyal aşınım ve mekanik çözünme almış, karstik aşınım şekilleri büyük ölçüde tahrip olmuştur.

Arapgir Platosu toprak, su ve vejetasyon açısından sınırlı olmakla birlikte, taşlık ve engebeli bir topoğrafyaya sahiptir. Bu durum, tarım açısından elverişsiz arazilere ve su yoksunluğuna yol açtığından platonun bu kısmında hemen hemen hiçbir daimi yerleşme bulunmamaktadır. Aynı zamanda karstlaşma arazi kullanımını da etkilemiş ve bu alanın yaylak-otlak alanı olarak kullanılmasını sağlamıştır.

Analizler sonucunda; karstik aşınım şekilleri ve nüfus varlığının yoğunluğu tespit edilerek, karstik aşınım şekillerinin ve de yerleşme ile nüfus varlığının konumu istatistiksel olarak saptanmıştır. Analiz sonuçlarına göre karstik aşınım şekillerinin

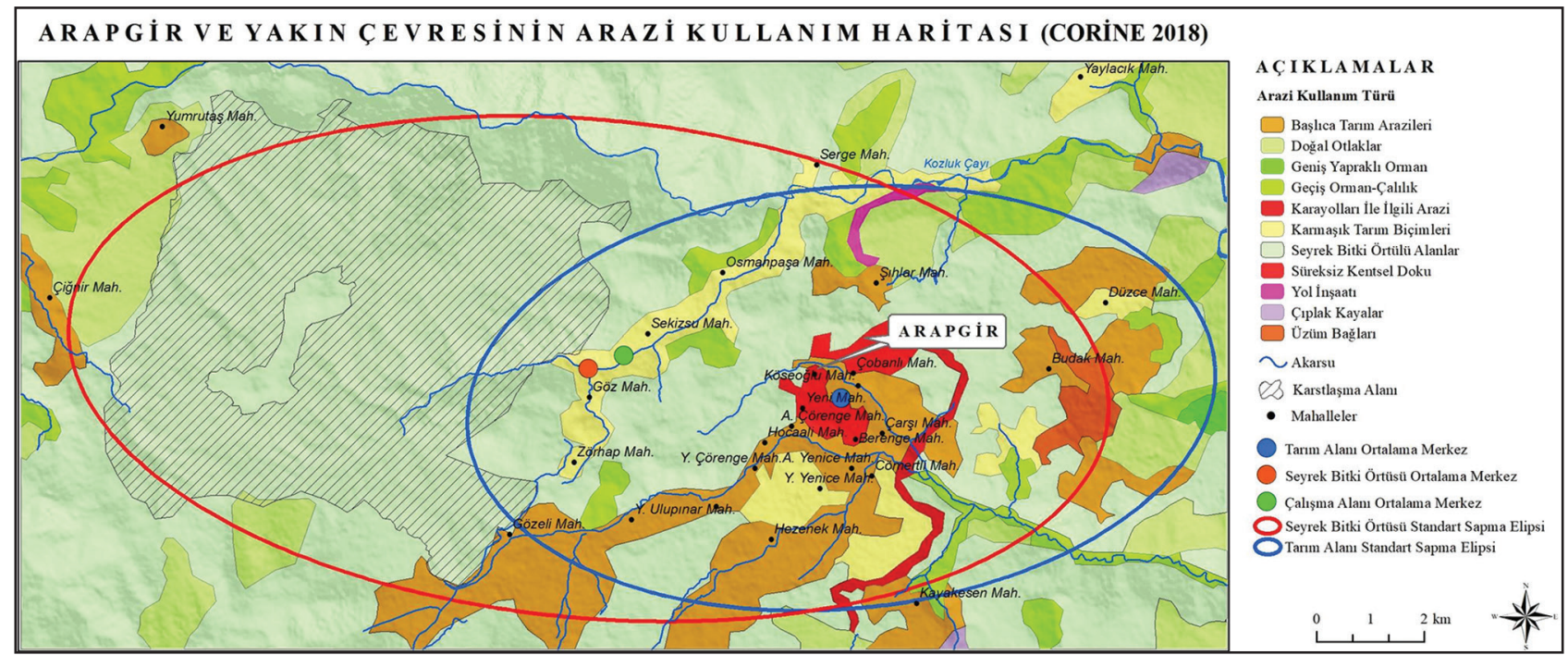

Şekil 8. CORINE (2018) verilerine göre Arapgir ve yakın çevresinin arazi kullanım haritası, seyrek bitki örtülü ve çeşitli tarım alanlarına göre Ortalama Merkez ve Standart Sapma Elipsi Analizi.

Figure 8. Land use map of Arapgir and its immediate surroundings according to CORINE (2018) data, Sparse plant cover and Average Center and Standard Deviation Ellipse Analysis by various agricultural areas. 
çalışma alanının batısında yüksek plato alanına denk gelecek şekilde yoğunluk kazandığı, yerleşmelerin ve nüfus varlığının ise çalışma alanın doğusunda tarımsal faaliyetler ve su potansiyeli açısından zengin, sığ karst oluşumunun görülmediği litolojik birimler üzerinde yoğunluk kazandığı saptanmıştır. Aynı zamanda seyrek bitki örtülü alanların genel ölçüde karstlaşma alanına denk gelecek şekilde batıda çeşitli tarım alanlarının ise Pliyosen yaşlı bazaltlar ile sığ karst gelişiminin görülmediği alanlara denk gelecek şekilde doğuda yoğunluk kazandığı saptanmıştr. Böylelikle karstlaşmanın, yerleşme seçimi ve arazi kullanımı üzerinde sınırlandırıcı bir etken olduğu istatistiksel olarak ispatlanmıştır.

Bu tarz CBS tabanlı mekânsal istatistik analizleri özellikle doğa ile insan arasındaki etkileşime odaklanan coğrafyacılar tarafindan kullanılarak, coğrafi çalışmalara kantitatif bir nitelik sağlanmalı ve çalışmaların geçerliliği arttırılmalıdır. Ayrıca bu analizler yönetim kadroları tarafindan, karstik alanların tespitinde ve bu alanlardaki yerleşme seçimi ile arazi kullanım durumunun saptanmasında kullanılarak, elde edilen bulgular planlama ve yatırım çalışmalarında altık olarak değerlendirilmelidir.

\section{Kaynakça}

Aktimur, H.T., Sarıaslan, M., Yurdakul, M.E., Keçer, M., Mutlu, G., Turşucu, A., Aktimur, S., Ölçer, S., \& Yıldırım, Y. (1995). Erzincan Dolayının Jeolojisi, (Rapor No: 9792). Maden Tetkik ve Arama Genel Müdürlüğü.

Baytaşoğlu, Z. (2011). Eski Arapgir (Malatya) civarındaki Miyo-Pliyosen birimlerinin kil mineralojisi ve kimyası (Tez No. 292710) [Yüksek Lisans Tezi, Fırat Üniversitesi]. Yök Tez.

Bögli, A. (1960). Kalklösung und Karrenbildung. İntern. Beitrage zur Karstmorphologie. Zeitsher F. Geomorphologie. Supplement Band 2.

Çelik, S. (2019). Yerleşmelerin seçiminde etkili olan coğrafi faktörler ve yanlış yer seçimlerinde risk analizi. Uluslararası Sosyal Araştirmalar Dergisi, 12(66), 334-342. https://dergipark.org.tr/tr/ pub/ecd/issue/58525/775792.

Doğan, U. (1997). Gidengelmez Dağları'nda doğal ortam ve insan ilişkileri. Ankara Üniversitesi Türkiye Coğrafyası Araştırma ve Uygulama Merkezi Dergisi, (6), 41-62. http://tucaum.ankara.edu.tr/ wp-content/uploads/sites/280/2015/08/tucaum6 4.pdf.

Doğan, U., Koçyiğit, A., \& Gökkaya, E. (2016). Development of the Kembos and Eynif structural poljes: Morphotectonic evolution of the Upper Manavgat River basin, central Taurides, Turkey, Geomorphology, 278, 105-120. https://doi.org/10.1016/i.geomorph.2016.10.030.

Doğan, U., \& Koçyiğit, A. (2018). Morphotectonic Evolution of Maviboğaz Canyon and Suğla Polje, SW Central Anatolia, Turkey, Geomorphology, 306, 13-27. https://doi.org/10.1016/i.geomorph.2018.01.001

Doğan, U., Koçyiğit, A., Yeşilyurt, S. (2019), The relationship between Kestel Polje system and the Antalya Tufa Plateau: Their morphotectonic evolution in Isparta Angle, Antalya-Turkey, Geomorphology, 334, 112-125. https://doi.org/10.1016/i.geomorph.2019.03.003

Erinç, S. (1954). Doğu Anadolu coğrafyası. İstanbul Üniversitesi Yayınları.
Erinç, S. (2015). Jeomorfoloji II. DER Yayınları.

Erol, O. (1992). Klimajeomorfoloji. İstanbul Üniversitesi Yayınları.

Ford, D.C, \& Williams, P., (2007). Karst hidrology and geomorphology, John Wiley \& Sons Ltd.

Güner, ì. (2001). Muğla ve çevresindeki yerleşmelerin gelişimlerini etkileyen coğrafi faktörler. Muğla Üniversitesi SBE Dergisi, (4), 1-31. https://dergipark.org.tr/tr/download/article-file/217412.

Güneysu, C. A. (1993). Kovada Gölü doğusunun (Isparta) karst jeomorfolojisi [Yayınlanmamış Doktora Tezi]. İstanbul Üniversitesi.

Hadimli, H., \& Bulut, i. (2008). Karstik alanlarda arazi kullanımı ve planlaması. In. A. Çağlar, M. Özgür, H. Yiğitbaşıoğlu, İ. Çiçek, M. Somuncu, U. Doğan, \& N.Türkoğlu (Eds.), TÜCAUM V. Coğrafya Sempozyumu Bildiri Kitabı (ss. 6-14). TÜCAUM.

İskender, C. (1994). Ağın-Arapgir çevresinin (Elazığ kuzeybatısı) jeomorfolojisi (Tez No. 378885) [Yüksek Lisans Tezi, Fırat Üniversitesi]. Yök Tez.

Kaymak, K. F. (2018). Dim Çayı Havzası'nda (Alanya) lapya çeşitliliği. Atatürk Üniversitesi Sosyal Bilimler Enstitüsü Dergisi, 22 (Özel Sayı), 2067-2092. https://dergipark.org.tr/tr/download/article-file/558086.

Keser, N. (2004). Bezirgan polyesi ve yakın çevresinin karst jeomorfolojisi. Türk Coğrafya Dergisi, (42), 11-46. https://dergipark.org. tr/tr/download/article-file/198544.

Koçak, i. (2003). Döşemealt platosu kuzeybatısında (Antalya) karst-orman tahribatı ilişkisi. Burdur Eğitim Fakültesi Dergisi, 4(5), 29-146.

Nazik, L., \& Tuncer, K. (2010). Türkiye karst morfolojisinin bölgesel özellikleri. Türk Speleoloji Dergisi, (1), 7-79.

Nazik, L., \& Poyraz, M. (2015). Türkiye karst morfolojisinde neotektoniğin rolü. İçinde M. Bahadır, A. Uzun, \& H. İ. Zeybek (Eds.), IV. Ulusal Jeomorfoloji Sempozyumu Bildiriler Kitabı (ss. 203-212). Jeomorfoloji Derneği.

Nazik, L., \& Poyraz, M. (2017). Türkiye karst jeomorfolojisi genelini karakterize eden bir bölge: Orta Anadolu Platoları kuşağı. Türk Coğrafya Dergisi(68), 43-56. https://doi.org/10.17211/ tcd.300414.

Nazik, L., Poyraz, M. \& Karabıyıkoğlu, M. (2019). Karstic Landscapes and Landforms in Turkey. In: Landscapes and Landforms of Turkey. Edt. Kuzucuoğlu, C., Çiner, A., Kazancı, N. Switzerland: Springer Internatonal Publishing.

Ölgen, K., M. (2016). Fiziki Coğrafya Arazi Çalışmalarında Örnekleme Yöntemleri. In N. Özgen, \& S. Karadoğan (Eds.), Fiziki Coğrafyada Araştırma Yöntemleri ve Teknikleri (ss.150-162). PEGEM Yayınları.

Özdemir, A. M., \& Yılmaz Kafalı, F., Gür, E., \& Kaymak, H. (2017) Dinar ilçesinde jeomorfolojik birimler ve arazi kullanımı. In $\mathrm{S}$. Tonbul, M. T. Şengün, M. Siler, \& F. A. Canpolat (Eds.), Uluslararası Jeomorfoloji Sempozyumu Bildiriler Kitabı (ss. 483-489). Jeomorfoloji Derneği.

Özer, E. (1994). Munzur Dağlarının (Kemah-iliç-Erzincan) stratigrafisi. Türkiye Jeoloji Bülteni, 37 (2), 53-64.

Özgül, N. (1981). Munzur Dağlarının jeolojisi (Rapor No. 6995). Maden Tetkik ve Arama Enstitüsü.

Öztürk, M. Z., Şimşek, M., Utlu, M., \& Şener, M. F. (2017). Karstic depressions on Bolkar Mountain plateau, Central Taurus (Turkey): Distribution characteristics and tectonic effect on orientation. Turkish Journal of Earth Sciences, 26(4), 302-313. 
Öztürk, M. Z. (2020). Fluvio-karstic evolution of the Taşeli Plateau (Central Taurus, Turkey). Turkish Journal of Earth Sciences, 29(5).

Pekcan, N. (2019). Karst jeomorfolojisi. Filiz Kitabevi.

Siler, M., \& Şengün, T., M. (2014). Taşeli platosunda (Anamur-Ermenek arası) jeomorfolojik özelliklerin insan faaliyetlerine etkisi. In E., Yılmaz (Edt.), TUCAUM VIII. Coğrafya Sempozyumu Bildiriler Kitabı (ss. 33-43). TÜCAUM.

Sönmez, M. (2004). Arapgir (Malatya) güneybatısındaki alanın stratigrafik ve tektonik özellikleri (Tez No. 150118) [Doktora Tezi, FIrat Üniversitesi]. Yök Tez.

Şaroğlu, F., \& Güner, Y. (1981). Doğu Anadolu jeomorfolojik gelişimine etki eden öğeler; jeomorfolojik, tektonik, volkanizma ilişkileri. Türkiye Jeoloji Bülteni, (24), 39-50. https://www.jmo.org.tr/ resimler/ekler/d863b367aa379f7 ek.pdf?dergi=T\%DCRK\%DDYE\%20JEOLOJ\%DD\%20B\%DCLTEN\%DD.

Tatar, Y. (1987). Elazığ bölgesinin genel tektonik yapıları ve Landsat fotoğrafları üzerinde yapılan bazı gözlemler. Yerbilimleri, (14), 295-308.

Tonbul, S. (1987). Elazığ batısının genel jeomorfolojik özellikleri ve gelişimi. Jeomorfoloji Dergisi, (15), 37-52.

Uysal, A. R. (2011). Fırat Nehri üzerindeki barajların (Keban, Karakaya, Atatürk) bölgenin yağış ve sıcaklık değerlerine etkisi (Tez No.277436) [Yüksek Lisans Tezi, Niğde Üniversitesi]. Yök Tez. 